\title{
Photochemical roles of rapid economic growth and potential abatement strategies on tropospheric ozone over South and East Asia in 2030
}

\author{
S. Chatani ${ }^{1}$, M. Amann ${ }^{2}$, A. Goel ${ }^{3}$, J. Hao ${ }^{4}$, Z. Klimont ${ }^{2}$, A. Kumar ${ }^{3}$, A. Mishra ${ }^{3}$, S. Sharma ${ }^{3}$, S. X. Wang ${ }^{4}$, \\ Y. X. Wang ${ }^{4}$, and B. Zhao ${ }^{4}$ \\ ${ }^{1}$ Toyota Central R\&D Labs., Inc., Nagakute, Japan \\ ${ }^{2}$ International Institute for Applied Systems Analysis, Laxenburg, Austria \\ ${ }^{3}$ The Energy and Resources Institute, New Delhi, India \\ ${ }^{4}$ Tsinghua University, Beijing, China
}

Correspondence to: S. Chatani (schatani@mosk.tytlabs.co.jp)

Received: 13 January 2014 - Published in Atmos. Chem. Phys. Discuss.: 8 April 2014

Revised: 25 July 2014 - Accepted: 28 July 2014 - Published: 9 September 2014

\begin{abstract}
A regional air quality simulation framework including the Weather Research and Forecasting modeling system (WRF), the Community Multi-scale Air Quality modeling system (CMAQ), and precursor emissions to simulate tropospheric ozone over South and East Asia is introduced. Concentrations of tropospheric ozone and related species simulated by the framework are validated by comparing with observation data of surface monitoring, ozonesondes, and satellites obtained in 2010. The simulation demonstrates acceptable performance on tropospheric ozone over South and East Asia at regional scale. Future energy consumption, carbon dioxide $\left(\mathrm{CO}_{2}\right)$, nitrogen oxides $\left(\mathrm{NO}_{\mathrm{x}}\right)$, and volatile organic compound (VOC) emissions in 2030 under three future scenarios are estimated. One of the scenarios assumes a business-as-usual (BAU) pathway, and other two scenarios consider implementation of additional energy and environmental strategies to reduce energy consumption, $\mathrm{CO}_{2}, \mathrm{NO}_{\mathrm{x}}$, and VOC emissions in China and India. Future surface ozone under these three scenarios is predicted by the simulation. The simulation indicates future surface ozone significantly increases around India for a whole year and around northeastern China in summer. $\mathrm{NO}_{\mathrm{x}}$ is a main driver on significant seasonal increase of surface ozone, whereas VOC as well as increasing background ozone and methane is also an important factor on annual average of surface ozone in East Asia. Warmer weather around India is also preferable for significant increase of surface ozone. Additional energy and environmental strategies assumed in future scenarios are
\end{abstract}

expected to be effective to reduce future surface ozone over South and East Asia.

\section{Introduction}

China, India, and other developing countries in Asia are accomplishing rapid economic growth. On the other hand, expanding economic activities have caused significant increase of energy consumption and carbon dioxide $\left(\mathrm{CO}_{2}\right)$ emissions as well as heavy air pollution. One of the key air pollutants is tropospheric ozone. Rising trends of tropospheric ozone have been observed at least in Japan (Kurokawa et al., 2009; Tanimoto, 2009), China (Xu et al., 2008; Tang et al., 2009; Wang et al., 2009), and India (Kulkarni et al., 2010). Ozone has adverse effects on human health (WHO, 2006) and vegetation (Mauzerall and Wang, 2001). In addition, tropospheric ozone is getting more attention as one of the short-lived climate pollutants (SLCPs). Reduction of tropospheric ozone may achieve co-benefits which would save human health and vegetation, and simultaneously mitigate near-term climate change (Shindell et al., 2012). Tropospheric ozone could be transported across countries, as its lifetime in the atmosphere is relatively long among air pollutants (Akimoto, 2003). Therefore, multilateral strategies would be desired to reduce tropospheric ozone at regional scale.

Ozone is not directly emitted from emission sources. It is formed in the atmosphere from precursors including 
nitrogen oxides $\left(\mathrm{NO}_{\mathrm{x}}\right)$ and volatile organic compounds (VOCs) via photochemical reactions. Numerical simulation models which represent photochemical reactions in the atmosphere are frequently applied to consider how to control precursor emissions in order to reduce tropospheric ozone. The community of global models has conducted several studies to predict future tropospheric ozone. For example, the Atmospheric Chemistry and Climate Model Intercomparison Project (ACCMIP) conducted the intercomparison of the tropospheric ozone (Young et al., 2013) and its radiative forcing (Stevenson et al., 2013) in past and future years simulated by the participating global models. However, there are limitations in these studies. One of them includes coarse resolutions applied in global models. They may not be suitable to simulate tropospheric ozone over densely polluted regions such as megacities in Asia. Another limitation consists of future scenarios. Global future scenarios originally for green house gases (GHGs) are often used in their studies. However, superficial extrapolations of GHGs to air pollutants would lead to misleading conclusions (Amann et al., 2013). ACCMIP utilized four Representative Concentration Pathways (RCPs) (Van Vuuren et al., 2011). RCPs have been developed on the basis of emissions and associated concentrations of greenhouse gases. Although emissions of atmospheric air pollutants are also estimated in RCPs, Van Vuuren et al. (2011) mentioned that there are limitations in the use of RCPs for specific air pollution applications because they assumed that air pollution control becomes more stringent just as a result of rising income levels. That means they imply an endogenous strengthening of legislation and compliance beyond what is currently agreed (Amann et al., 2013). Moreover, each RCP has been developed by different modeling groups. Their assumptions on socioeconomic drivers and climate policies are not necessarily consistent. Therefore, differences among RCPs cannot be directly interpreted as effects of specific policies. They are not suitable to consider what, when, and how strategies should be implemented in individual countries to suppress tropospheric ozone.

This paper describes a prediction of tropospheric ozone over South and East Asia in 2030 in future scenarios by using three-dimensional regional air quality simulations of which the resolution is much finer than global models. Several studies applied regional air quality simulations in East Asia. For example, Yamaji et al. (2008) conducted simulations to predict future surface ozone over East Asia. Kurokawa et al. (2009) and Chatani and Sudo (2011) showed good performances of the simulations to reproduce the trend of surface ozone over Japan for past years. Although applications in South Asia are limited, Kumar et al. (2012) described extensive validation of the regional simulations applied over South Asia. One of the outstanding features of this study is the domain covering China and India together, which are both key developing countries in Asia. Three future scenarios were developed in this study. The first scenario assumed a business-as-usual pathway. Future changes in $\mathrm{NO}_{\mathrm{x}}$ and VOC emissions not only in China but also all the other Asian countries including India were estimated. The second scenario assumed implementation of additional energy strategies aiming at reducing energy consumption and $\mathrm{CO}_{2}$ emissions in China and India. They also resulted in reduction of $\mathrm{NO}_{\mathrm{x}}$ and VOC emissions. The third scenario assumed implementation of additional environmental strategies aiming at reducing $\mathrm{NO}_{\mathrm{x}}$ and $\mathrm{VOC}$ emissions in China and India in addition to energy strategies. The purpose of this study is to evaluate effects of potential energy and environmental strategies implemented in China and India on tropospheric ozone over South and East Asia based on simulated results for three future scenarios. Abatement costs required to implement these strategies were also estimated. The information regarding the effects and associated abatement costs of various energy and environmental strategies in China and India obtained in this study would be helpful to consider effective energy and environmental policies which should be introduced in both countries to suppress tropospheric ozone as well as energy consumption and $\mathrm{CO}_{2}$ emissions. It must be noted that the horizontal resolution of the regional air quality simulations is $60 \mathrm{~km} \times 60 \mathrm{~km}$. Therefore, it cannot inherently represent a horizontal variation below $60 \mathrm{~km} \times 60 \mathrm{~km}$. The target of this study is regional tropospheric ozone above this horizontal scale, which is not directly affected by local sources.

Section 2 describes details of the three-dimensional regional air quality simulation framework organized in this study. Section 3 evaluated model performances on tropospheric ozone and related species. Section 4 discusses simulated results of future tropospheric ozone. The outcomes obtained in this study are summarized in Sect. 5. Note that this paper mainly focuses on air quality simulations. Details of estimating energy consumption, precursor emissions, and abatement costs are described elsewhere (see Sect. 2.2).

\section{Simulation setup}

\subsection{Model configurations}

The Community Multi-scale Air Quality modeling system (CMAQ) (Byun and Schere, 2006) version 5.0.1 was applied to simulate concentrations of ambient gaseous and aerosol species including ozone. Gas-phase chemistry was represented in the Carbon Bond 05 mechanism with updated toluene chemistry (CB05-TU) (Whitten et al., 2010). Aerosol processes were represented in the AERO6 module. Meteorological inputs were obtained by running the Weather Research and Forecasting modeling system (WRF) - Advanced Research WRF (WRF-ARW) (Skamarock et al., 2008) version 3.4.1. The European Centre for Medium-Range Weather Forecasts (ECMWF) interim reanalyses (ERA-Interim) (Dee et al., 2011), and the daily, high-resolution, real-time, global, sea surface temperature (RTG_SST) analyses compiled by the National Centers for Environmental Prediction (NCEP) 
were used for initial and boundary conditions as well as grid nudging in WRF-ARW.

The target domains of WRF-ARW and CMAQ are shown in Fig. 1. It covers southern, eastern, and Southeast Asian countries including Japan in the east, Mongolia in the north, Pakistan in the west, and Indonesia in the south. The horizontal resolution is $60 \mathrm{~km} \times 60 \mathrm{~km}$. 41 vertical layers are set from the ground to $5639 \mathrm{~Pa}$ above (approximately $19.5 \mathrm{~km}$ ) in WRF-ARW, and they are collapsed into 28 layers in CMAQ. The bottom layer height is approximately $34 \mathrm{~m}$ in both models.

Boundary concentrations of CMAQ were retrieved from the results of Model for Ozone and Related chemical Tracers, version 4 (MOZART-4) (Emmons et al., 2010) which was driven by the meteorological fields simulated by the Goddard Earth Observing System Model, version 5 (GEOS-5). They were obtained from the National Center for Atmospheric Research (NCAR, 2013). They were updated every $6 \mathrm{~h}$, and were temporally and spatially interpolated to the boundaries of the domain.

All the simulations discussed in this paper were performed for 14 months from November 2009 to December 2010 whereas results for the first month were discarded as a spinup period. Future changes in meteorological fields were not considered in this study.

\subsection{Energy and emission data}

We estimated energy consumption and emissions of various species including $\mathrm{CO}_{2}$ in 2010 (referred as BASE) in 22 Asian countries (Bangladesh, Bhutan, Brunei, Cambodia, China, India, Indonesia, Japan, North Korea, South Korea, Laos, Malaysia, Mongolia, Myanmar, Nepal, Pakistan, the Philippines, Singapore, Sri Lanka, Taiwan, Thailand, and Vietnam). We also developed three future scenarios (BAU0, $\mathrm{PC} 0$, and PC1) which were designed following the concept of Xing et al. (2011) for 2030. BAU0 assumed a business as usual pathway. The energy and environmental legislations which have been currently determined were reflected in BAU0. PC0 assumed additional legislations and technological developments to suppress energy consumption and $\mathrm{CO}_{2}$ emissions in China and India. PC1 assumed additional legislations and technological developments to improve air quality in China and India besides PC0. Socioeconomic drivers like population and gross domestic product (GDP) were consistent in all the scenarios. Differences between BAU0 and $\mathrm{PC} 0$, and PC0 and PC1 correspond to effects of additional energy and environmental strategies implemented in China and India, respectively. It should be noted that future changes in emissions of species except for $\mathrm{CO}_{2}, \mathrm{NO}_{\mathrm{x}}$, and VOC were not considered in this study. PCO and PC1 considered additional energy and environmental strategies implemented only in China and India. Energy consumption and emissions in the countries except for China and India are the same in BAU0, $\mathrm{PC} 0$, and PC1. The following subsections briefly introduce

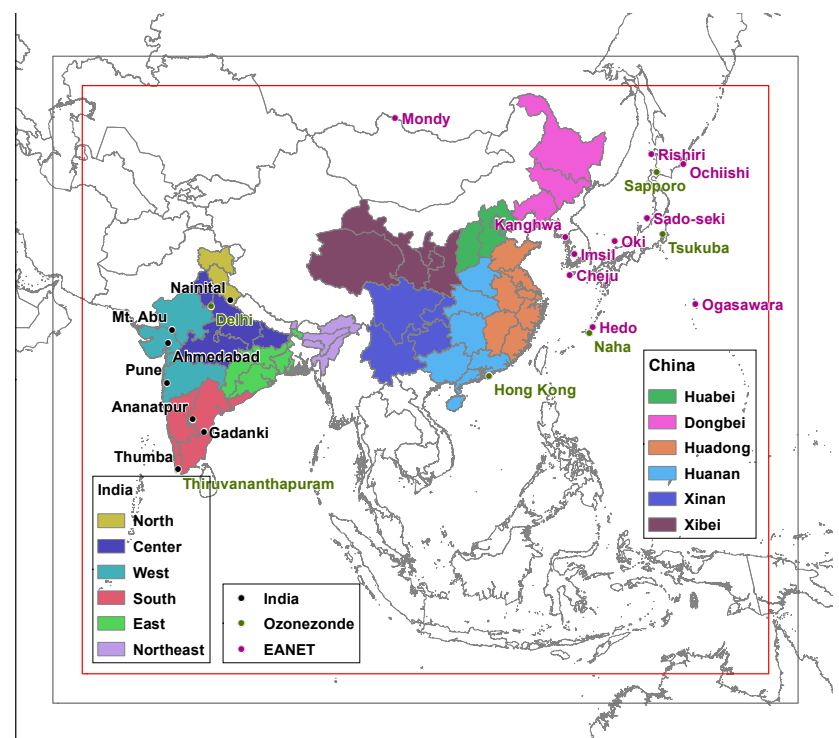

Figure 1. Target domains of WRF-ARW (gray) and CMAQ (red). Monitoring sites of Acid Deposition Monitoring Network in East Asia (EANET), ozonesonde, and India are indicated. Regions in China and India are color-coded.

them, whereas detailed descriptions of methodologies are found in references shown therein.

\subsubsection{China}

The database of anthropogenic energy consumption and emissions in China used in this study has been originally developed by Wang et al. (2011) and Xing et al. (2011) for current and future years. This study used the database recently updated by Zhao et al. (2013a, b, c). Emissions of sulphur dioxide, ammonia, $\mathrm{PM}_{10}, \mathrm{PM}_{2.5}$, black carbon, and organic carbon as well as $\mathrm{CO}_{2}, \mathrm{NO}_{\mathrm{x}}$, and VOC have been estimated for current years. VOC emissions have been speciated into CB05 species groups (Wei et al., 2008). The horizontal resolution of the data used in this study is $36 \mathrm{~km} \times 36 \mathrm{~km}$.

The annual energy consumption and $\mathrm{CO}_{2}, \mathrm{NO}_{\mathrm{x}}$, and VOC emissions estimated for 2010 (BASE) and 2030 under the three future scenarios in China are shown in Table 1. The $\mathrm{VOC} / \mathrm{NO}_{\mathrm{x}}$ emission ratios are also shown. The energy consumption increases by $64 \%$ from BASE to BAU0 due to growing economic activities. The $\mathrm{CO}_{2}$ emissions increase in similar magnitude by $66 \%$. Increases of the $\mathrm{NO}_{\mathrm{x}}$ and VOC emissions are $35 \%$ and $27 \%$, which are relatively lower than that of energy consumption. Current environmental legislations effectively reduce $\mathrm{NO}_{\mathrm{x}}$ and VOC emissions per energy consumption. The additional energy strategies assumed in $\mathrm{PC} 0$ realizes $22 \%, 30 \%, 29 \%$, and $16 \%$ decreases of the energy consumption and $\mathrm{CO}_{2}, \mathrm{NO}_{\mathrm{x}}$, and VOC emissions, respectively. They make the $\mathrm{NO}_{\mathrm{x}}$ and VOC emissions comparable to those in BASE. The additional environmental strategies assumed in $\mathrm{PC} 1$ further reduce the $\mathrm{NO}_{\mathrm{x}}$ and 
Table 1. Annual energy consumption and $\mathrm{CO}_{2}, \mathrm{NO}_{\mathrm{x}}$, and VOC emissions estimated for 2010 (BASE) and 2030 under three future scenarios. $\mathrm{VOC} / \mathrm{NO}_{\mathrm{x}}$ emission ratios are also shown.

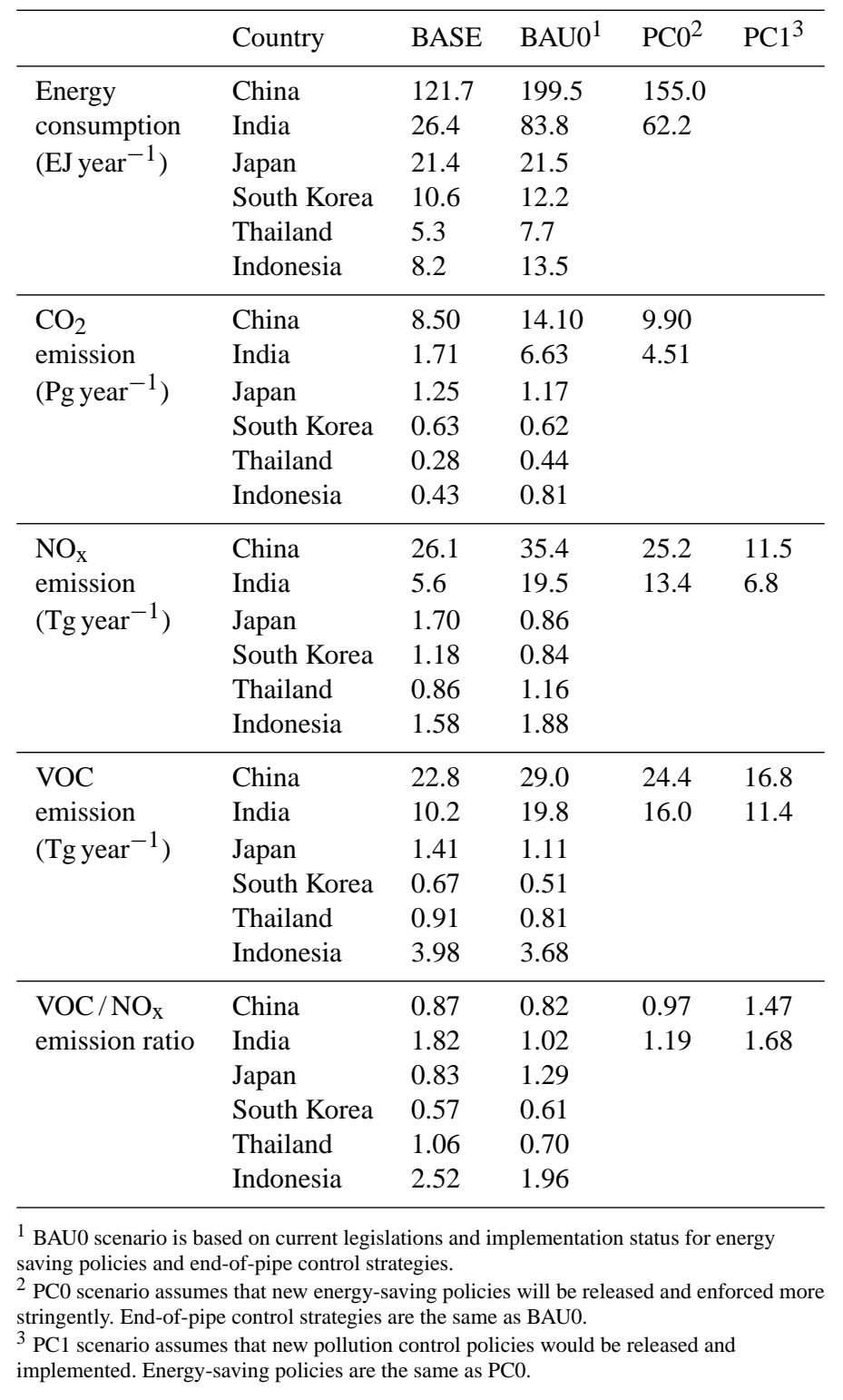

VOC emissions by $55 \%$ and $31 \%$, which become significantly lower than those in BASE. The $\mathrm{VOC} / \mathrm{NO}_{\mathrm{x}}$ ratio increases from 0.82 in BAU0 to 1.47 in $\mathrm{PC} 1$ as $\mathrm{NO}_{\mathrm{x}}$ is more effectively reduced than VOC by the assumed energy and environmental strategies.

\subsubsection{India}

The database of anthropogenic energy consumption and emissions in India used in this study has been developed by Sharma et al. (2014). Emissions of carbon monoxide, sulphur dioxide, and total suspended particulates (TSP) as well as $\mathrm{CO}_{2}, \mathrm{NO}_{\mathrm{x}}$, and VOC have been estimated for current years. VOC emissions have been speciated into CB05 species groups. The horizontal resolution of the data used in this study is $36 \mathrm{~km} \times 36 \mathrm{~km}$.

The annual energy consumption and emissions estimated for 2010 (BASE) and 2030 under the three future scenarios in India are shown in Table 1. The energy consumption and $\mathrm{CO}_{2}$ emissions dramatically increase by 3.2 and 2.9 times from BASE to BAU0 due to rapid economic growth assumed in the scenarios ( $8 \%$ per year). The $\mathrm{NO}_{\mathrm{x}}$ emissions also increase by 3.5 times. Although legislations to reduce $\mathrm{NO}_{\mathrm{x}}$ emissions have been already implemented, growing economy increases dependence on coal power plants, heavy industries, and vehicles, of which $\mathrm{NO}_{\mathrm{x}}$ emissions per energy consumption is relatively high. On the other hand, magnitude of increase of the VOC emissions is less than twice. 
The assumed decrease of dependence on biomass fuel in domestic use, which is the dominant VOC emission source in BASE, suppresses increase of VOC emissions. That also results in significant changes of the $\mathrm{VOC} / \mathrm{NO}_{\mathrm{X}}$ ratios. It is 1.82 in BASE, which is much higher than China, and decreases to 1.02 in BAU0. The additional energy strategies assumed in PC0 realizes $26 \%, 32 \%, 31 \%$, and $20 \%$ decreases of the energy consumption and $\mathrm{CO}_{2}, \mathrm{NO}_{\mathrm{x}}$, and VOC emissions, respectively. The additional environmental strategies assumed in $\mathrm{PC} 1$ further reduce the $\mathrm{NO}_{\mathrm{x}}$ and VOC emissions by $49 \%$ and $29 \%$, which become comparable to those in BASE. The $\mathrm{VOC} / \mathrm{NO}_{\mathrm{x}}$ ratio increases to 1.68 in $\mathrm{PC} 1$ as $\mathrm{NO}_{\mathrm{x}}$ is effectively reduced than VOC by energy and environmental strategies as in the case of China.

\subsubsection{Other Asian countries}

The data of anthropogenic energy consumption and emissions in Asian countries other than China and India were obtained from the results of the Greenhouse Gas and Air Pollution Interactions and Synergies (GAINS)-Asia model (Klimont et al., 2009; Amann et al., 2011) using World Energy Outlook 2011 (IEA, 2011) energy projections. GAINSAsia has a capability to estimate energy consumption and emissions in 99 regions in Asia. In addition, the gridded data of which the horizontal resolution is $0.5^{\circ} \times 0.5^{\circ}$ are also available (IIASA, 2013). The results of GAINS-Asia model for 99 regions were used to develop speciation factors for each sector, fuel and region based on SPECIATE 4.3 (USEPA, 2013) because the detailed information of sectors and fuels are available. Then, they were applied to the gridded data to convert VOC emissions into CB05 species groups.

The annual energy consumption and emissions estimated for 2010 (BASE) and 2030 (BAU0) in major Asian countries (Japan, South Korea, Thailand, and Indonesia) are shown in Table 1. Japan and South Korea indicate a different pathway from Thailand and Indonesia. The energy consumption and $\mathrm{CO}_{2}$ emissions are comparable for BASE and BAU0 in Japan and South Korea. The $\mathrm{NO}_{\mathrm{x}}$ and VOC emissions in BAU0 are lower than BASE in both countries. On the other hand, energy consumption and emissions of $\mathrm{CO}_{2}$ and $\mathrm{NO}_{\mathrm{x}}$ significantly increase from BASE to BAU0 in Thailand and Indonesia. Decrease of the VOC emissions in Thailand and Indonesia in BAU0 is mainly due to decrease of 2-wheel motorcycles in vehicles fleets.

\subsubsection{Other emissions}

Monthly values in the Global Fire Emissions Database (GFED) (Van der Werf et al., 2010) version 3.1 were applied for biomass burning emissions. Emissions from agricultural burning in GFED were ignored because they are included in the anthropogenic emissions described in previous subsections. Emission Database for Global Atmospheric Research
(EDGAR) version 4.1 (European Commission, 2010) was applied for international shipping emissions. Hourly biogenic emissions were estimated by the Model of Emissions of Gases and Aerosols from Nature (MEGAN) (Guenther et al., 2006) version 2.04. Future changes in these emissions were not considered in this study.

\section{Model performance}

A simulation for the case using emissions for 2010 (BASE) was performed. Horizontal distributions of the simulated seasonal mean surface ozone concentration are shown in Fig. 2a. Note that averaged values of daily $8 \mathrm{~h}$ maximum ozone concentration within the bottom 3 layers (approximately $134 \mathrm{~m}$ ) are discussed as mean surface ozone concentration hereafter in this paper because they are the most relevant to consider adverse effects on human health and vegetation. Notable seasonal features are found in horizontal distributions. A zone with high concentration encompasses mid-latitude regions from India to Japan in spring and autumn. It is shifted northward and the highest concentration appears around northeastern China in summer. On the contrary, the concentration significantly decreases around the same region in winter. The concentration is low for a whole year around the equator while some hot spots are found around megacities. Excited oxygen atoms, which are dissociated from ozone, are likely to be scavenged by abundant water vapor instead of reproducing ozone.

The simulated results of ozone and related species were compared with observations to validate them as discussed in following subsections. Although it should be avoided to use the observation data directly affected by local sources, some data had to be included due to limited data availability in the target region. We additionally relied on the satellite data. Its great advantage is comparisons between observed and simulated values which are both consistently averaged in the same individual meshes. It is suitable to validate the regional air quality simulations in this study.

\subsection{Surface ozone}

Surface ozone concentration is continuously observed at the Acid Deposition Monitoring Network in East Asia (EANET) monitoring sites. It is an ideal monitoring network to validate the simulations in this study because the monitoring sites are mainly located in remote areas. Ten monitoring sites classified as "Rural" and "Remote" were picked up to avoid sites affected by local sources (Network Center for EANET, 2012). The monthly mean surface ozone concentration observed at these sites and the corresponding values simulated in the bottom layer are compared as shown in Fig. 3. The results of MOZART-4 in its bottom layer are also shown in it. The locations of the twelve EANET monitoring sites are 
(a) BASE for 2010
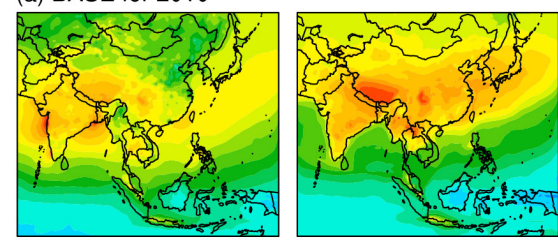

(b) BAU0 for 2030

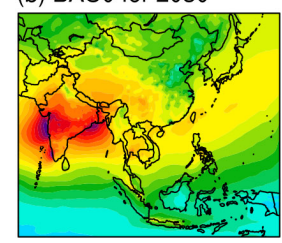

(c) PC1 for 2030

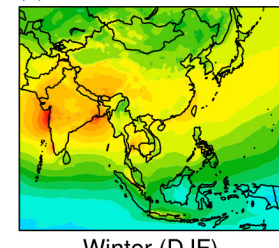

Winter (DJF)
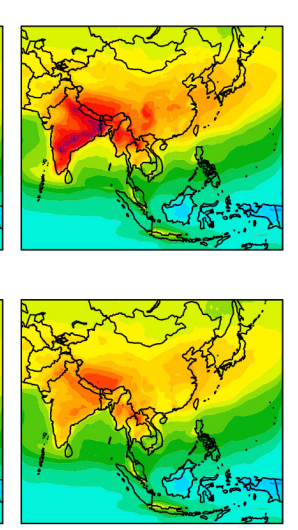

Spring (MAM)
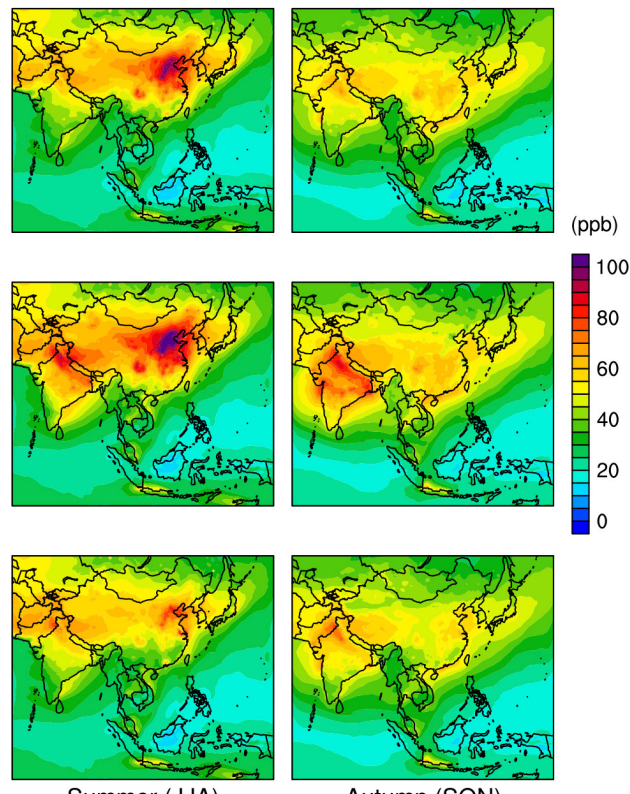

Summer (JJA)

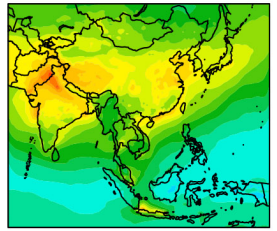

Autumn (SON)

Figure 2. Horizontal distributions of simulated seasonal mean surface ozone concentration in (a) BASE for 2010, (b) BAU0 for 2030, and (c) PC1 for 2030 .

indicated in Fig. 1. Most of them are located in Japan and South Korea.

The observed values are high in spring and low in summer. Peak values and seasonal variations are reasonably reproduced by the simulation. One of the problems is that the low values observed in summer are overestimated in the simulation at several sites. Such a tendency is more evident in the results of MOZART-4. The simulation in this study makes effectively the simulated values closer to the observed ones as realized at Rishiri and Ochiishi. However, declines of the observed values in summer are still not fully reproduced at Sado-seki, Oki, Cheju, and Imsil, which are located in or around Japan Sea. It appears that the simulation in this study and MOZART-4 share common difficulties in reproducing low values around Japan Sea in summer. Southerly winds are dominant but westerly winds also appear for some days in summer around Japan and South Korea. Relationships between the hourly surface ozone and wind direction at Sado-seki and Oki were investigated (not shown). It turned out that westerly winds mainly cause overestimation at both sites. The simulated values are the highest around upwind regions of westerly winds in summer as shown in Fig. 2a. Lin et al. (2009) and Chatani and Sudo (2011) have showed that surface ozone was overestimated around corresponding regions in their simulations. Excess ozone may be transported downwind to South Korea and Japan on westerly winds and cause overestimation in this study, too. Lin et al. (2009) implied surface ozone is highly sensitive to cloud cover and monsoonal rainfall over these regions. Chatani and Sudo (2011) mentioned uncertainties in emission inventory and coarse resolution as well as potential missing pathways in the chemical mechanisms embedded in the model as possible reasons for overestimation. The simulation in this study as well as MOZART-4 may still have similar difficulties in accurately representing these factors.

There is no monitoring network similar to EANET in South Asia. Kumar et al. (2012) validated their simulation by comparing the simulated monthly mean values of surface ozone with the observed data at the seven sites in India which had been published in the past literatures. The target years of the observed data were not necessarily consistent with their simulation. We follow Kumar et al. (2012), though a part of the data is substituted with the data published in more recent literatures. As a result, the observed data of surface ozone at Ahmedabad (Lal et al., 2000), Gadanki (Naja and Lal, 2002), Mt. Abu (Naja et al., 2003), Pune (Beig et al., 2007), Anantapur (Reddy et al., 2012), Nainital (Kumar et al., 2010), and Thumba (David and Nair, 2011) were picked up in this study. The locations of these seven sites are indicated in Fig. 1. Some of them are not located in remote areas. The monthly mean surface ozone concentration observed at them and the corresponding values simulated in the bottom layer are compared as shown in Fig. 4. The results of MOZART-4 in its bottom layer are also shown in it.

The observed values are high in late winter or spring, and low in summer. Such seasonal variations are generally reproduced in most sites including Anantapur, where the target year of the observed values is coincident with the simulation. The model performance at all the sites is comparable to Kumar et al. (2012). One of the notable differences 

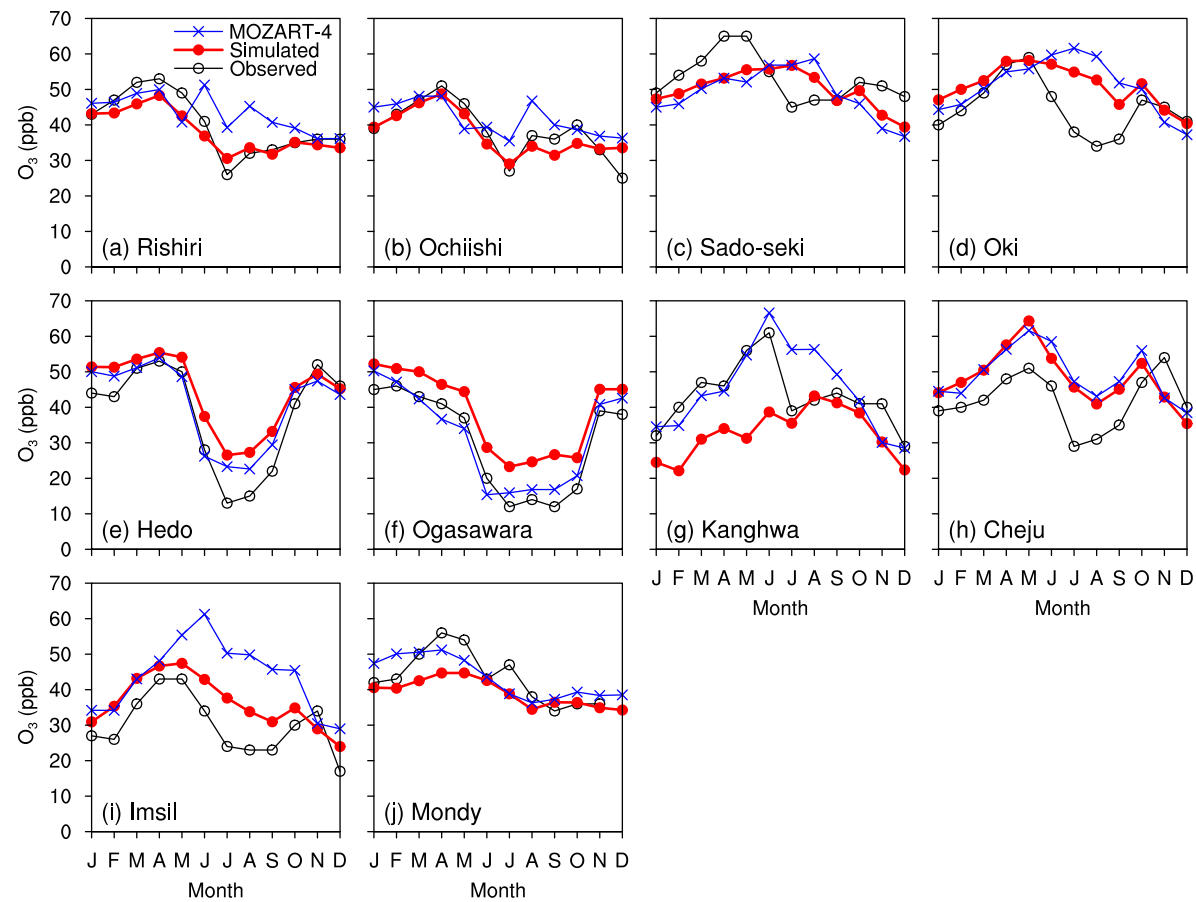

JFMAM J JASOND JFMAM J JASOND Month Month

Figure 3. Monthly mean observed and simulated surface ozone concentration in BASE for 2010 at 10 EANET monitoring sites. Results of MOZART-4 are also shown.
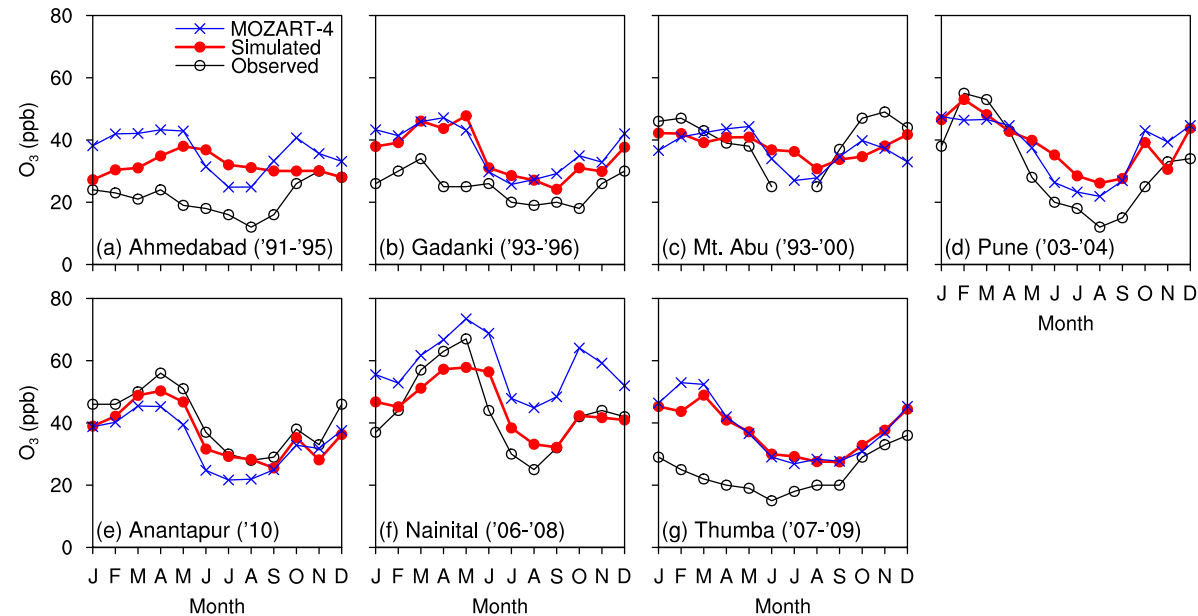

Month

Figure 4. Monthly mean observed and simulated surface ozone concentration in BASE for 2010 at seven sites in India. Results of MOZART-4 are also shown. Target years of observations are shown along site names.

between them is amplitudes of seasonal variations. Kumar et al. (2012) showed better performance on low values in summer, though peak values in winter were significantly overestimated. The performance of the simulation in this study is opposite to them. Peak values in winter are reasonably reproduced whereas low values in summer are slightly overestimated. The reason is probably due to seasonal variations in emissions. Information regarding seasonal variations in emissions in India have not been available in the database described in Sect. 2.2.2, whereas Kumar et al. (2012) applied seasonal variations represented in the Reanalysis of Tropospheric Chemical Composition (RETRO) database. The model performance in this study could be improved if any seasonal variations in emissions are applied. In addition, the total amount of $\mathrm{NO}_{\mathrm{x}}$ emissions developed in this study for India is less than the Intercontinental Chemical Transport Experiment - Phase B (INTEX-B) inventory (Zhang et al., 2009) which was used in Kumar et al. (2012). It may prevent significant overestimation of surface ozone in winter in this study. 


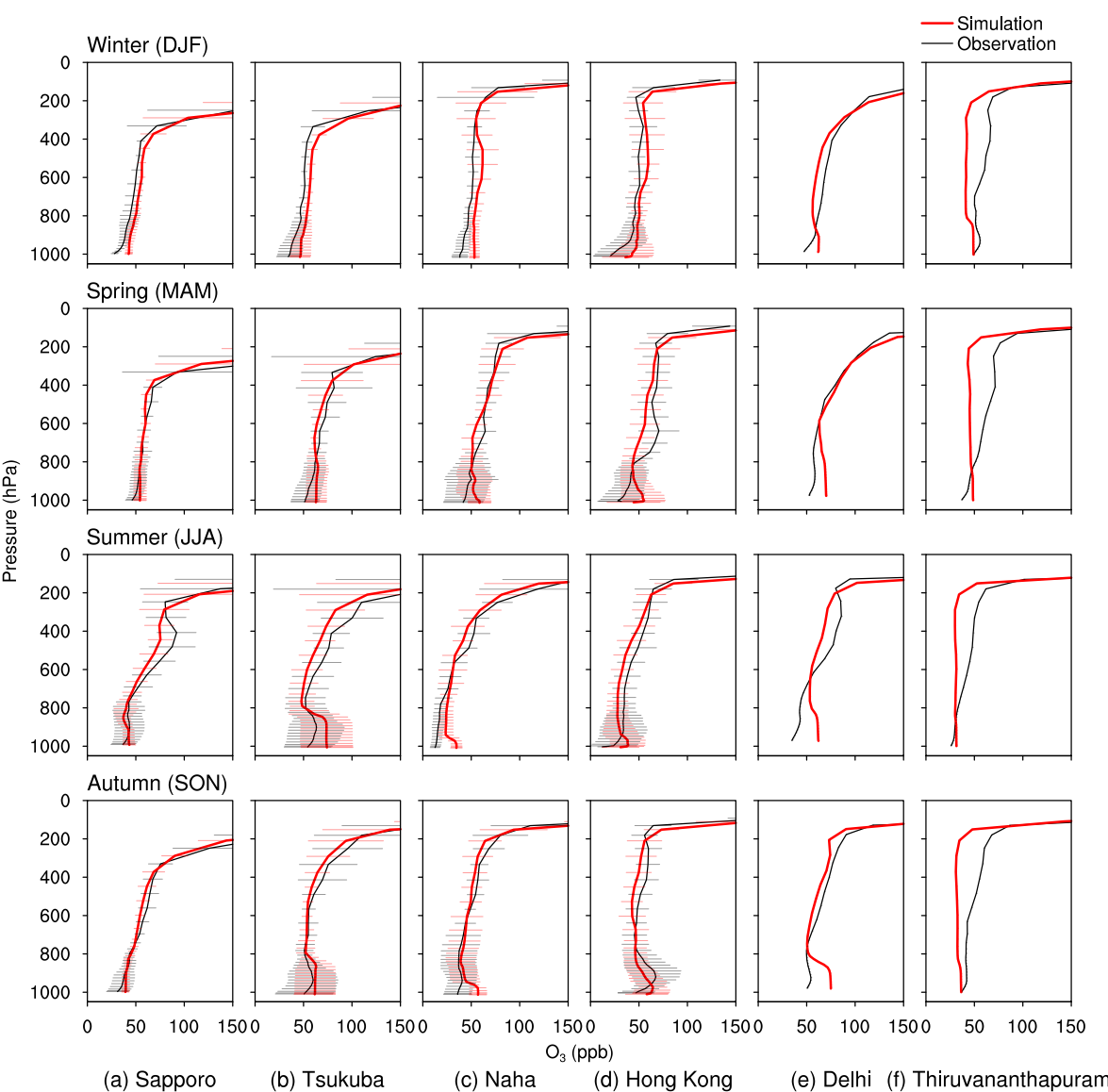

Figure 5. Vertical profiles of observed and simulated ozone concentration in BASE for 2010 at six monitoring stations. Values are averaged over all ozonesonde measurements within each season at Sapporo, Tsukuba, Naha, and Hong Kong. Error bars represent standard deviations. Simulated seasonal mean values are compared with values averaged over all available ozonesonde measurements within each season during 2000-2011 at Delhi and Thiruvananthapuram.

The surface ozone is overestimated in Ahmedabad and Thumba throughout the year. The station in Ahmedabad is located in the urban area (Lal et al., 2000). The station in Thumba is located $10 \mathrm{~km}$ away from the city center (David and Nair, 2011). It appears that the observed values at the both stations are affected by local sources. MOZART- 4 also overestimates the values at the both stations, implying a limitation to reproduce low values with the current horizontal resolution. Simulated ozone around local sources is influenced by a horizontal resolution, and its temporal mean values tend to become lower with higher resolution (Chatani et al., 2011). Such a low value affected by local sources is not the target of this study.

\subsection{Vertical ozone profile}

Vertical concentration profiles of the simulated ozone were compared with those of the ozone observed by ozonesonde at three stations (Sapporo, Tsukuba, and Naha) in Japan (JMA, 2012), one station in Hong Kong (Hong Kong Observatory, 2012), and two stations (Delhi and Thiruvananthapuram) in
India (India Meteorological Department, 2013) which are archived by World Ozone and Ultraviolet Radiation Data Centre (WOUDC). The locations of the six stations are shown in Fig. 1. Vertical profiles of the observed and simulated values at them are compared as shown in Fig. 5. Measurements have been conducted several times in each season at Sapporo, Tsukuba, Naha, and Hong Kong. Both of the observed and simulated values at these four stations are those averaged over all the measurements conducted within each season. On the other hand, any values observed at Delhi and Thiruvananthapuram in 2010 are not available. Therefore, the simulated seasonal mean values are compared with the observed values averaged over all the available measurements in each season during 2000-2011 in Fig. 5 following Kumar et al. (2012). High gradients of the values observed in the upper troposphere are well reproduced by the simulation. The older versions of CMAQ had a problem in simulating them adequately when results of global scale models were utilized as boundary concentrations (Lam and $\mathrm{Fu}$, 2009). The latest version of CMAQ used in this study has 


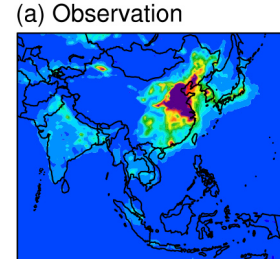

(b) Simulation

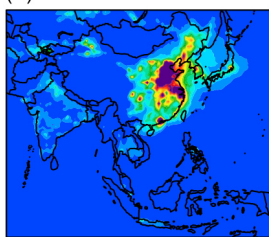

Winter (DJF)
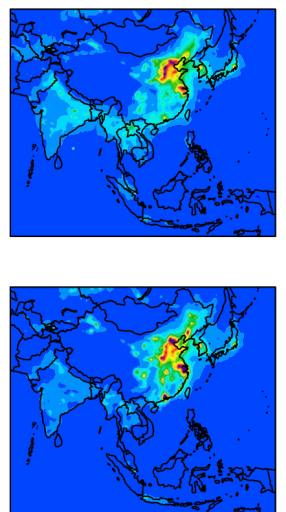

Spring (MAM)
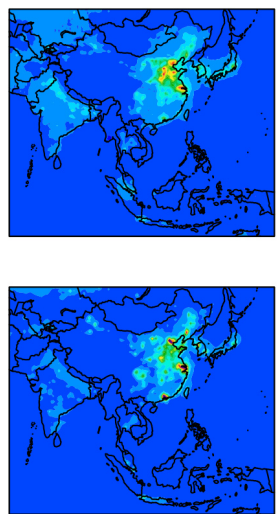

Summer (JJA)
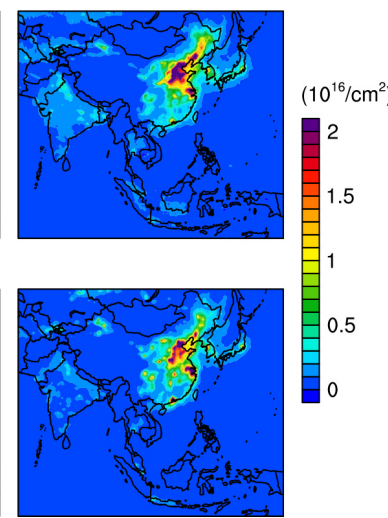

Autumn (SON)

Figure 6. Horizontal distributions of observed and simulated seasonal mean tropospheric column $\mathrm{NO}_{2}$ in $\mathrm{BASE}$ for 2010.

updated the representation of turbulent mixing during stable conditions and updates to the vertical advection scheme to reduce numerical diffusion in the upper model layers. It appears this update has contributed to significant improvement of the performance on vertical profile. The profiles in the lower and middle troposphere are also well reproduced, but the simulated values tend to be slightly higher around the surface and lower in the middle troposphere than the observed values except for Thiruvananthapuram. The simulated values are almost constant from the surface up to $200 \mathrm{hPa}$ whereas a weak gradient are found in the values observed at Thiruvananthapuram. Uncertainties in vertical diffusions may result in deviations between the observed and simulated values, and cause excessive accumulation of ozone in summer in the lower layers of the simulation shown in Figs. 3 and 4.

\subsection{Tropospheric column $\mathrm{NO}_{2}$}

Tropospheric column $\mathrm{NO}_{2}$, which is one of the major precursors of ozone, has been retrieved from the observations of the Ozone Monitoring Instrument (OMI) mounted on the Earth Observing System (EOS) Aura satellite. The second release of collection $3 \mathrm{OMI} /$ Aura Level-2 $\mathrm{NO}_{2}$ data product OMNO2 (Bucsela et al., 2013) available at the National Aeronautics and Space Administration (NASA) Goddard Earth Sciences Data and Information Services Center (2012) was used in this study. The retrieved data of tropospheric column $\mathrm{NO}_{2}$ within the target domain without any problems were selected based on their quality flags. The corresponding simulated value at the same location and timing were also picked up. Horizonal distributions of their seasonal mean values are shown in Fig. 6. The observed and simulated monthly mean values averaged over the regions shown in Fig. 1 in China and India as well as other major countries (Japan, South Korea, Thailand, and Indonesia) are shown in Fig. S1 in the Supplement.
The observed values are high around populated regions including the North China Plain (Huabei), the Yangtze River delta (Huadong), the Pearl River Delta (Huanan), Seoul (South Korea), and Tokyo (Japan) in East Asia. They indicate a clear seasonal variation with high values in winter and low values in summer. These features are well reproduced by the simulation as shown by Wang et al. (2011) which used the consistent emissions with this study. The values are systematically lower in South and Southeast Asia because $\mathrm{NO}_{\mathrm{x}}$ emissions are significantly lower than East Asia. Note that the ranges of tropospheric column $\mathrm{NO}_{2}$ in Fig. S1 in the Supplement are different in East and South/Southeast Asia. The values are underestimated by the simulation except for summer in South and Southeast Asia. As discussed in Sect. 3.1, possible reasons of underestimated $\mathrm{NO}_{2}$ are the total amount and seasonal variation of $\mathrm{NO}_{\mathrm{x}}$ emissions developed in this study. Ghude et al. (2013) derived $1.9 \mathrm{TgN}_{\text {year }}{ }^{-1}$ as the optimized total amount of $\mathrm{NO}_{\mathrm{x}}$ emissions for India in 2005 by using an inverse technique and iterative procedure to minimize gaps between their simulated values and the observed values derived from OMI. The total amount of $\mathrm{NO}_{\mathrm{x}}$ emissions developed in this study for India discussed in Sect. 2.2.2 is equivalent to $1.7 \mathrm{TgN}_{\text {year }}{ }^{-1}$. If economic growth during 20052010 is taken into account, the $\mathrm{NO}_{\mathrm{x}}$ emissions developed in this study seems to be underestimated. Kumar et al. (2012) showed their simulation overestimated tropospheric column $\mathrm{NO}_{2}$ over the Indo-Gangetic Plain (center) in winter, and underestimated it in rest of seasons and regions. Such a spatial difference in the performance is not found in this study. The horizontal distribution of the $\mathrm{NO}_{\mathrm{x}}$ emissions developed in this study may prevent accumulating $\mathrm{NO}_{\mathrm{x}}$ in Indo-Gangetic Plain.

\subsection{Total column CO}

$\mathrm{CO}$ is also an important precursor of ozone as well as a product in photochemical reactions involving VOCs. Therefore, 


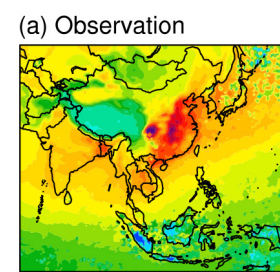

(b) Simulation

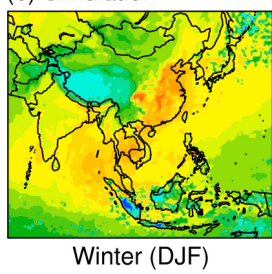

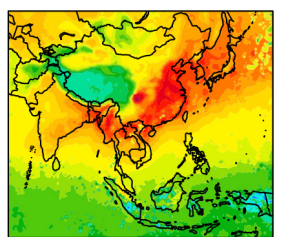

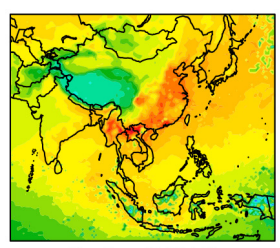

Spring (MAM)
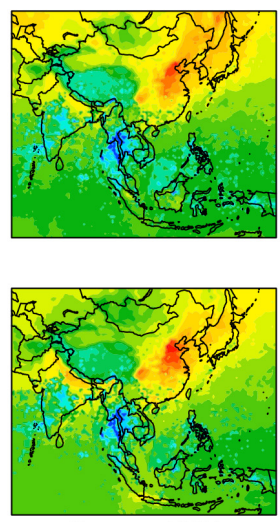

Summer (JJA)
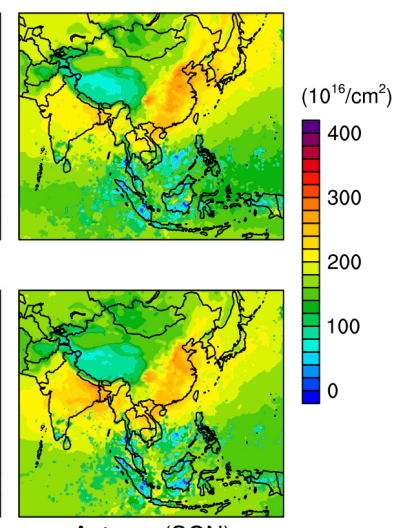

Autumn (SON)

Figure 7. Horizontal distributions of observed and simulated seasonal mean total column CO in BASE for 2010.

validations for $\mathrm{CO}$ are valuable in terms of ozone formation and VOC emissions. Total column CO has been retrieved from the observations of the Measurements Of Pollution In The Troposphere (MOPITT) mounted on the Earth Observing System (EOS) Terra satellite. The MOPITT Version 4 (Deeter et al., 2010) Level 2 product was used in this study. The retrieved data of total column CO within the target domain without any problems were selected based on their quality flags. The corresponding simulated value at the same location and timing were also picked up. Horizonal distributions of their seasonal mean values are shown in Fig. 7. The observed and simulated monthly mean values averaged over the regions are shown in Fig. S2 in the Supplement.

The observed values are high from winter to spring in eastern China, the Indochina peninsula, and India. The values in the Indochina peninsula and India become much lower in summer and autumn. Such a seasonal variation is well reproduced by the simulation, though the higher values from winter to spring are slightly underestimated in this study. Biomass burning is active in the corresponding regions and the seasons in which the observed values are high. It implies that the GFED biomass burning emissions used in this study are underestimated. Pechony et al. (2013) also indicated that the GFED emissions are significantly underestimated in South and Southeast Asia in their inverse modeling using MOPITT and Tropospheric Emission Spectrometer (TES) satellite data.

\subsection{Tropospheric column ozone}

Ziemke et al. (2006) has derived tropospheric column ozone by subtracting stratospheric column ozone observed by Microwave Limb Sounder (MLS) mounted on EOS from total column ozone observed by OMI. The data of their monthly mean tropospheric column ozone was obtained from the NASA Goddard Space Flight Center (2012). Horizonal distributions of their seasonal mean values are shown in Fig. 8.
The simulated values at the locations and timings from the surface up to the tropopause at which total column ozone was retrieved by OMI without any problems were picked up based on quality flags of the version 3 of the OMI/Aura Ozone Total Column Level-2 data product (OMTO3). The tropopause was determined as the height at which a gradient of temperature becomes lower than $2 \mathrm{~K} \mathrm{~km}^{-1}$ in the values simulated by WRF (Kumar et al., 2012) above $316 \mathrm{hPa}$, which is the lowest altitude retrieved from MLS. Horizonal distributions of their seasonal mean values are also shown in Fig. 8. The observed and simulated monthly mean values averaged over the regions are shown in Fig. S3 in the Supplement.

The observed values are high over the mid latitude in spring. The zone with high values is shifted northward in summer, and causes elevated values over northeast China. Such features in horizontal distribution are well reproduced in the simulation. The observed values are highest in summer in most of East Asia as shown in Fig. S3 in the Supplement whereas surface ozone shown in Fig. 3 in corresponding regions is lowest in summer. The observed and simulated values in all months agree well in Huabei where surface ozone is highest in summer. Therefore, uncertainties in vertical profiles of ozone shown in Fig. 5 may be a major factor causing overestimation of surface ozone in East Asia as discussed in Sect. 3.3. The simulated values are higher than the observed ones over the mid latitude in winter. The difference between observed and simulated monthly column ozone is $12 \mathrm{DU}(37.9 \%)$ in January in the center (India), and the difference between observed and simulated seasonal column ozone is 8.0 DU (24\%) in DJF in the same region at the maximum. Ziemke et al. (2006) showed that the column ozone simulated by Global Modeling Initiative's (GMI) Combined Stratosphere-Troposphere Chemical Transport Model (COMBO CTM) is 5-10 DU higher than the value obtained from OMI/MLS in DJF in the 

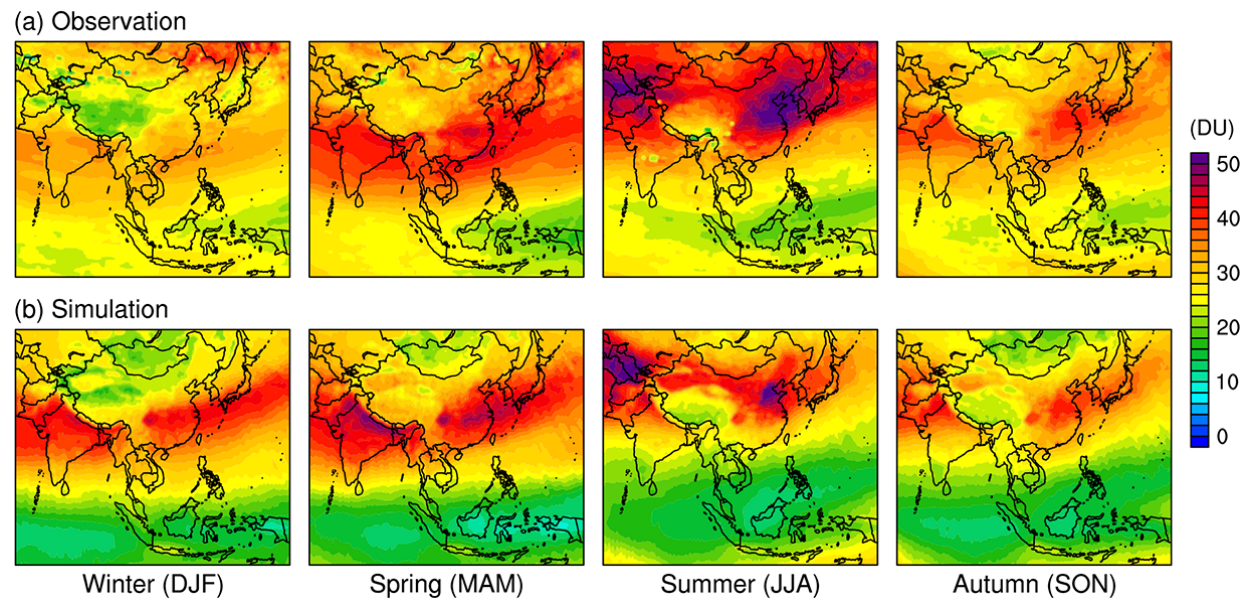

Figure 8. Horizontal distributions of observed and simulated seasonal mean tropospheric column ozone in BASE for 2010.

Table 2. Overview of simulation cases performed in this study.

\begin{tabular}{lll}
\hline Case & Emission & Other change \\
\hline BASE & BASE & \\
BAU0nox & BAU0 $\left(\mathrm{NO}_{\mathrm{x}}\right.$ only) + BASE & \\
BAU0voc & BAU0 (VOC only) + BASE & \\
BAU0 & BAU0 & \\
BAU0o3 & BAU0 & $+5 \mathrm{ppb}$ boundary ozone \\
BAU0ch4 & BAU0 & $+400 \mathrm{ppb}$ background methane \\
BAU0ta & BAU0 & $-5^{\circ} \mathrm{C}$ temperature \\
PC0 & PC0 & \\
PC1 & PC1 & \\
\hline
\end{tabular}

corresponding region. The model performance in this study is comparable to them.

Although some issues which should be solved to improve the model performance on ozone still remain, we have come to the conclusion that the regional air quality simulation framework constructed in this study has acceptable performance to predict tropospheric ozone at regional scale based on validations described in this section.

\section{Future prediction}

Simulations for the nine cases shown in Table 2 were performed to examine various factors on surface ozone in 2030. Future changes of surface ozone from 2010 to 2030 were evaluated in BASE and BAUO cases. Only $\mathrm{NO}_{\mathrm{x}}$ and VOC emissions were changed from BASE to BAU0 in BAU0nox and BAU0voc cases, respectively, to evaluate their effects separately. Boundary ozone concentration was homogeneously increased by $5 \mathrm{ppb}$ in BAU0o3 to evaluate potential effects of increasing background ozone on tropospheric ozone within the target domain. Similarly, homogeneous methane concentration was increased by $400 \mathrm{ppb}$ from the value used in the default CMAQ (1850 ppb) in
BAU0ch4 to evaluate potential effects of increasing background methane. The ranges of increasing background ozone and methane were set based on the maximum changes predicted by Dentener et al. (2006). Temperature was homogeneously decreased by $5^{\circ} \mathrm{C}$ in BAU0ta to see sensitivities of temperature on surface ozone. Effects of the additional energy and environmental strategies on surface ozone in 2030 were evaluated in $\mathrm{PC} 0$ and $\mathrm{PC} 1$.

\subsection{Future surface ozone in the BAU scenario}

Horizontal distributions of the seasonal mean surface ozone concentration simulated in BASE and BAU0 are shown in Fig. 2a and b, respectively. Significant increase of surface ozone around India in BAU0 is evident in all seasons. Dentener et al. (2006) also indicated significant increase of future ozone around India under their current legislation (CLE) scenario. Surface ozone around northeastern China in BAU0 is similarly higher in summer whereas it is slightly lower in winter than BASE.

Horizontal distributions of differences in the simulated seasonal mean surface ozone concentrations between BAU0nox and BASE, BAU0voc and BASE, and BAU0 and BASE are shown in Fig. 9. Increase of surface ozone around 
(a) BAU0nox-BASE

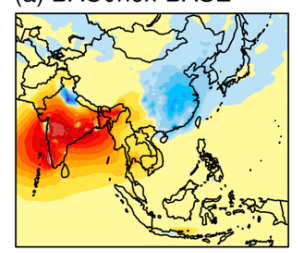

(b) BAUOvoc-BASE

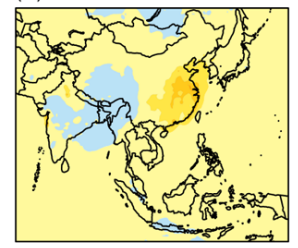

(c) BAU0-BASE

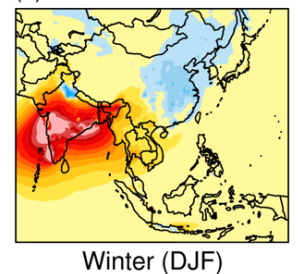

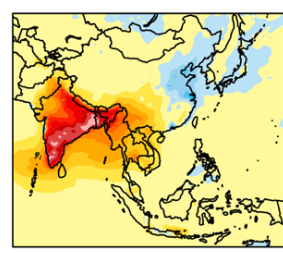
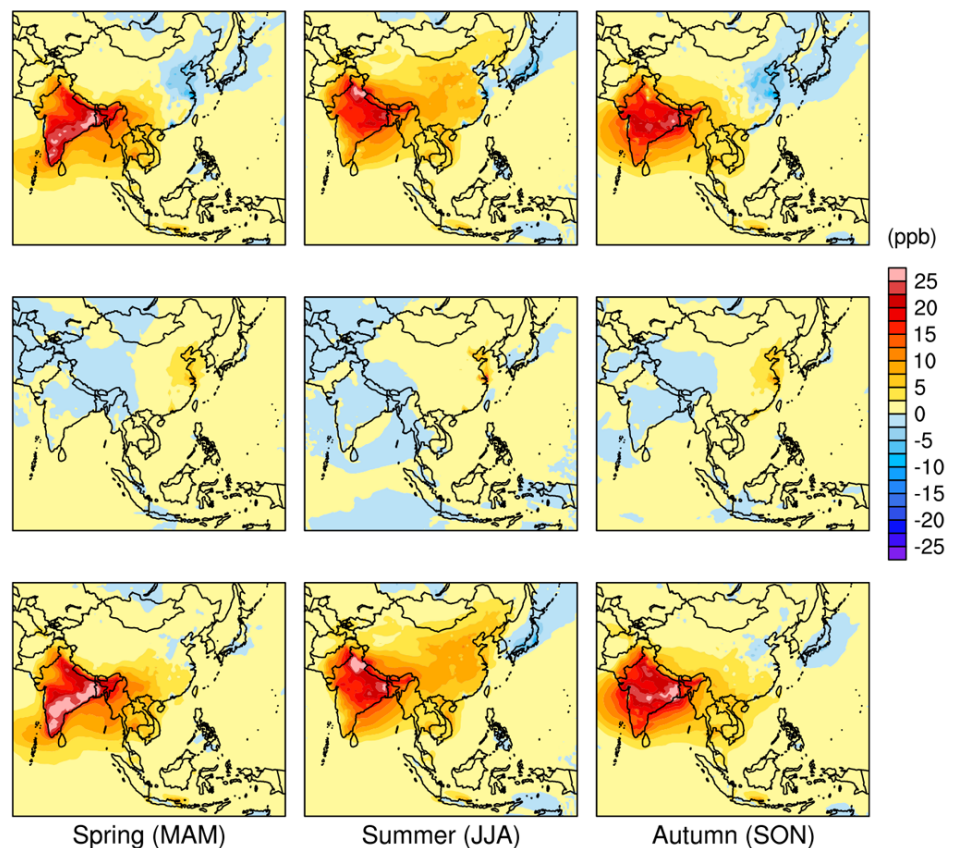

Summer (JJA)

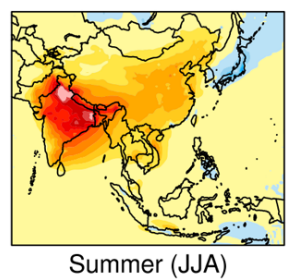

Autumn (SON)

Figure 9. Horizontal distributions of differences in simulated seasonal mean surface ozone concentrations between (a) BAU0nox and BASE, (b) BAU0voc and BASE, and (c) BAU0 and BASE.

India and surrounding regions including southwestern China and Indochina in all seasons is exclusively affected by increasing $\mathrm{NO}_{\mathrm{x}}$. The effects of VOC are negligible or slightly negative around those regions. Increase of surface ozone over most of China in summer is also much affected by increasing $\mathrm{NO}_{\mathrm{x}}$ except for megacities like the Yangtze River delta and the Pearl River delta while its magnitude is less than India. Ozone chemistry in India for the whole year and in China in summer seems to be in the $\mathrm{NO}_{\mathrm{x}}$-sensitive regime (Sillman, 1999). Kumar et al. (2012) also implied that the ozone chemistry over India is $\mathrm{NO}_{\mathrm{x}}$-limited except for a part of the Indo-Gangetic Plain in winter. On the other hand, negative effects of increasing $\mathrm{NO}_{\mathrm{x}}$ appear around northeastern China in spring and autumn, and they expand throughout the whole of eastern China in winter. Increasing VOC has positive effects around the corresponding regions. Ozone chemistry in eastern China in winter seems to be in the VOCsensitive regime. Liu et al. (2010) indicated that ozone chemistry in eastern China is in the VOC-sensitive regime in January and the $\mathrm{NO}_{\mathrm{x}}$-sensitive regime in July. They also indicated that it is in the $\mathrm{NO}_{\mathrm{x}}$-sensitive regime in central and western China and in the VOC-sensitive regime in major Chinese megacities throughout the year. Itahashi et al. (2013) suggested that the regime of ozone chemistry in East Asia is $\mathrm{NO}_{\mathrm{x}}$-sensitive in summer, VOC-sensitive in winter, and either $\mathrm{NO}_{\mathrm{x}^{-}}$- or VOC-sensitive during spring and autumn. The results obtained in this study are consistent with their findings. Factors that affect $\mathrm{NO}_{\mathrm{x}}-$ and the $\mathrm{VOC}$-sensitive regimes include $\mathrm{VOC} / \mathrm{NO}_{\mathrm{x}}$ ratios as well as meteorological conditions (Sillman, 1999). Table 1 shows $\mathrm{VOC} / \mathrm{NO}_{\mathrm{x}}$ ratios in BASE are much higher in India than China. They may result in stronger sensitivities of $\mathrm{NO}_{\mathrm{x}}$ around India. Effects of $\mathrm{NO}_{\mathrm{x}}$ are negative in all seasons, and those of VOC are also negative in summer around Japan and South Korea. Although a part of them may be affected by transport from China, decrease of domestic $\mathrm{NO}_{\mathrm{x}}$ and VOC emissions should contributes to decrease of surface ozone around this region.

\subsection{Effects of external factors on future surface ozone}

Horizontal distributions of differences in the simulated seasonal mean surface ozone concentrations between BAU0o3 and BAU0, and BAU0ch4 and BAU0 are shown in Fig. 10. The effect of boundary ozone is reduced around regions where a lot of chemical species are emitted and react with ozone. Decrease of the effect is more evident in summer due to more active photochemical reactions. The effect is also lower around tropical regions with abundant water vapor. Nevertheless, increasing boundary ozone may cause a few ppb increase of surface ozone throughout the domain especially in winter over mid-latitude regions as discussed by Chatani and Sudo (2011). By contrast, the effect of background methane increases around regions where a lot of chemical species are emitted. Products from methane in photochemical reactions contribute to net increase of ozone originating in $\mathrm{NO}_{\mathrm{x}}$. However, magnitude of the effect of background methane is only a few ppb at a maximum against a large increase of background methane $+400 \mathrm{ppb}$. It is 
(a) BAU003-BAU0

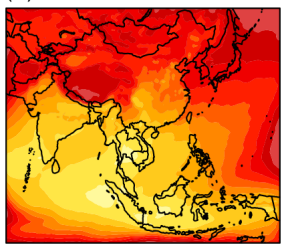

(b) BAU0ch4-BAU0

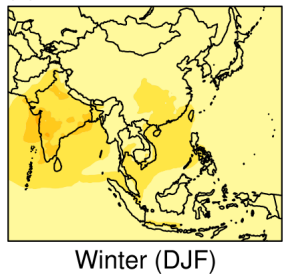

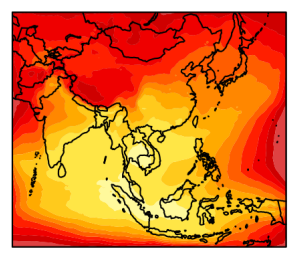

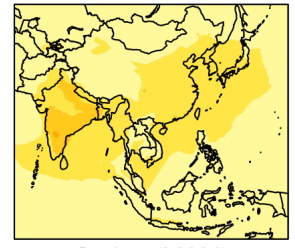

Spring (MAM)
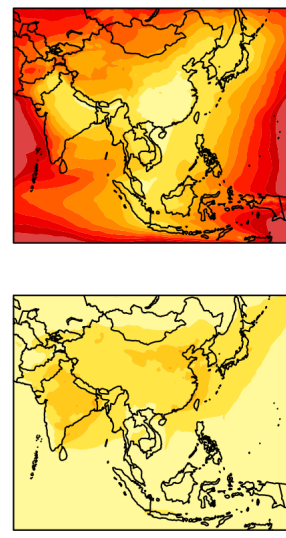

Summer (JJA)
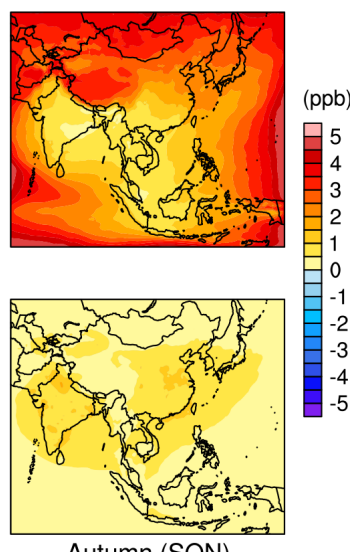

Autumn (SON)

Figure 10. Horizontal distributions of differences in simulated seasonal mean surface ozone concentrations between (a) BAU0o3 and BAU0, and (b) BAU0ch4 and BAUO.
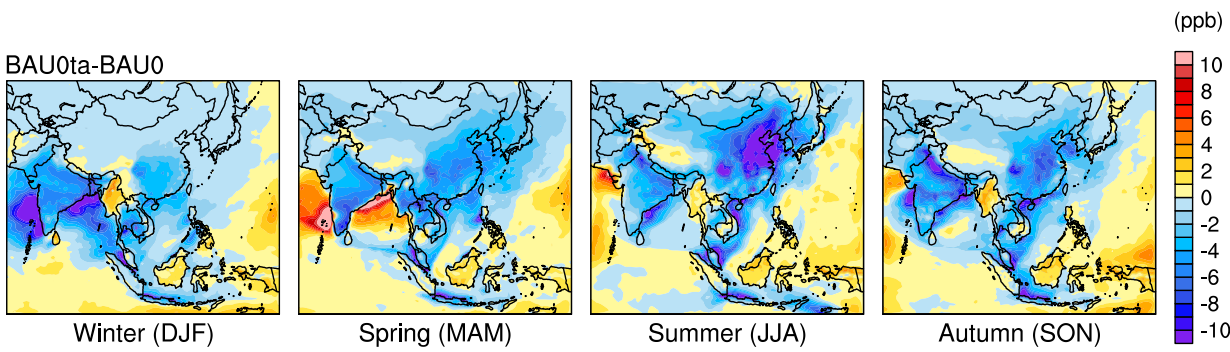

Figure 11. Horizontal distributions of differences in simulated seasonal mean surface ozone concentrations between BAU0ta and BAU0.

compensated with effect of boundary ozone, and combined effects of boundary ozone and background methane do not exceed $5 \mathrm{ppb}$. Note that the relatively small effect of increasing background methane does not deny its importance on surface ozone described by Dentener et al. (2005) and Fiore et al. (2008). Increasing background methane causes a part of increase of background ozone. The effect of boundary ozone evaluated in this section is partly affected by background methane.

Horizontal distributions of differences in the simulated seasonal mean surface ozone concentrations between BAU0ta and BAU0 are shown in Fig. 11. Negative effect of decreased temperature is found around regions where surface ozone is abundant such as India for the whole year and northeastern China in summer. The motivation to conduct this sensitivity analysis is to investigate reasons why surface ozone significantly increases around India for the whole year while it decreases around China in winter even if $\mathrm{NO}_{\mathrm{x}}$ emissions are increased in both countries in BAU0. It turns out that higher temperature is one of the factors which cause higher ozone concentration. The weather condition around India is warm throughout the year. Therefore, increase of precursor emissions has larger importance in terms of ozone formation in India.

\subsection{Effects of energy and environmental strategies on future surface ozone}

Horizontal distributions of the seasonal mean surface ozone concentration simulated in PC1 are shown in Fig. 2c. Surface ozone concentration in PC1 is comparable or slightly lower than BASE. Horizontal distributions of differences in the simulated seasonal mean surface ozone concentrations between PCO and BAU0 and PC1 and BAU0 are shown in Fig. 12. Surface ozone is effectively reduced by the additional energy and environmental strategies around the regions in which it significantly increases from BASE to BAUO. Though, the regions with increasing ozone are found around eastern China where ozone chemistry is in the VOC-sensitive regime. They do not mean that energy and environmental strategies are not preferable to mitigate air pollution. Ozone isopleths against $\mathrm{NO}_{\mathrm{x}}$ and $\mathrm{VOC}$ have non-linear shapes (Sillman, 1999). If $\mathrm{NO}_{\mathrm{x}}$ is reduced in the VOC-sensitive regime, ozone should increase until it goes into the $\mathrm{NO}_{\mathrm{X}}-$ sensitive regime. It is essential to reduce $\mathrm{NO}_{\mathrm{x}}$ to pass over the ridge which divides the VOC- and $\mathrm{NO}_{\mathrm{x}}$-sensitive regimes and go into the $\mathrm{NO}_{\mathrm{x}}$-sensitive regime where ozone is effectively reduced. As shown in Fig. 12, the regions with increasing ozone are shrunk in spring and autumn. They imply that 


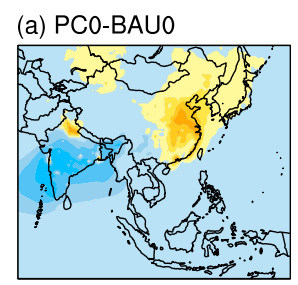

(b) PC1-BAU0

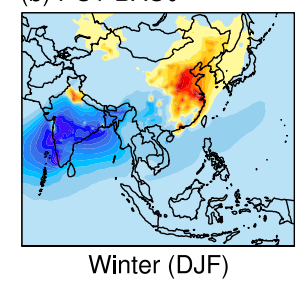

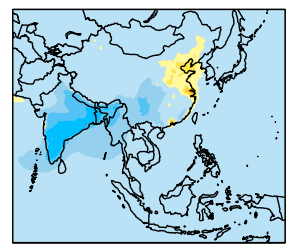

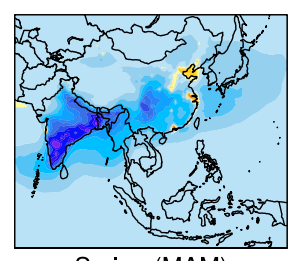

Spring (MAM)
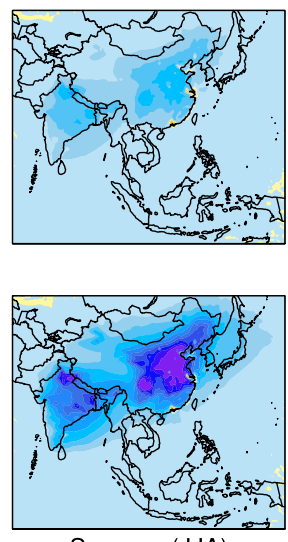

Summer (JJA)
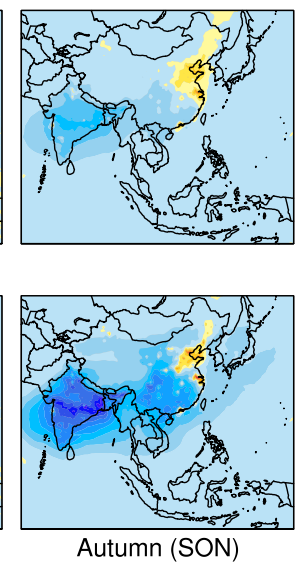

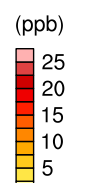

日 0

Figure 12. Horizontal distributions of differences in simulated seasonal mean surface ozone concentrations between (a) PC0 and BAU0, and (b) PC1 and BAU0.

the regime of ozone chemistry changes from VOC-sensitive to $\mathrm{NO}_{\mathrm{x}}$-sensitive as $\mathrm{VOC} / \mathrm{NO}_{\mathrm{x}}$ ratios increase due to more effective reduction of $\mathrm{NO}_{\mathrm{x}}$ than VOC as shown in Table 1. However, it is difficult to reduce ozone in winter around eastern China. In fact, surface ozone is lower than surrounding regions as shown in Fig. 2 b because titration by $\mathrm{NO}_{\mathrm{x}}$ overwhelms ozone formation. Reduction of $\mathrm{NO}_{\mathrm{x}}$ brings surface ozone back to its background level. Nonetheless, it is still necessary to reduce $\mathrm{NO}_{\mathrm{x}}$ because its products like $\mathrm{NO}_{2}$ and nitrate are also significant air pollutants.

\subsection{Regional summary}

Figure 13 shows differences in the simulated monthly mean surface ozone concentrations among cases which are averaged over regions shown in Fig. 1 in China and India as well as other major countries (Japan, South Korea, Thailand, and Indonesia). As discussed in previous sections, different characteristics are found in eastern (Huabei, Dongbei, Huadong, and Huanan) and western (Xinan and Xibei) China. Surface ozone increases from BASE to BAU0, and is effectively reduced in PC0 and PC1 for whole year in western China as well as in India. Although similar responses are found in eastern China in summer, increase of $\mathrm{NO}_{\mathrm{x}}$ from BASE to BAU0 results in decrease of surface ozone in winter. The additional energy and environmental strategies implemented in China and India assumed in PC0 and PC1 are effective to reduce surface ozone even in South Korea and Japan in summer. Decreasing domestic $\mathrm{NO}_{\mathrm{x}}$ in BAU0 also contributes to decrease of surface ozone in summer in Japan. Whereas the difference between BAU0voc and BASE is negligible in India, BAU0-BASE* (the difference between BAU0 and BASE in which the difference between BAUOnox and BASE and the difference between BAUOvoc and BASE are excluded) is evident. It means that sum of the individual effects of increasing $\mathrm{NO}_{\mathrm{x}}$ and increasing VOC does not coincide with the combined effects of increasing $\mathrm{NO}_{\mathrm{x}}$ and VOC. It implies that VOC has some effects on surface ozone in BAU0 in which the $\mathrm{VOC} / \mathrm{NO}_{\mathrm{x}}$ ratio is significantly lower than BASE. The additional energy and environmental strategies implemented in India and China assumed in PCO and PC1 are effective to reduce surface ozone in late autumn in Thailand where surface ozone increases due to increasing $\mathrm{NO}_{\mathrm{x}}$ in BAU0. Changes of surface ozone are negligible in Indonesia while the situation may be different around megacities locally.

Figure 14 shows the differences in the simulated annual mean surface ozone concentrations among cases which are averaged over regions in China and India as well as other major countries. Note that the ranges of vertical axis are different in East Asia (left) and South and Southeast Asia (right). The response in each case is simple and consistent with monthly concentrations in South and Southeast Asia. The increase of annual surface ozone reaches $20 \mathrm{ppb}$ in Indian regions. Fiore et al. (2012) showed that past model studies predicted 10-15 ppb increase of surface ozone in South Asia during 2000-2030 in the Special Report on Emission Scenarios (SRES) A2 scenario. $\mathrm{NO}_{\mathrm{x}}$ emission in India doubles for corresponding years in this scenario. This study predicted much larger increase of $\mathrm{NO}_{\mathrm{x}}$ emission in India as shown in Table 1. Therefore, the significant increase of surface ozone predicted in this study appears to be consistent in the past model studies shown in Fiore et al. (2012). On the other hand, the response of annual surface ozone is much more complex in East Asia. The effects of increasing $\mathrm{NO}_{\mathrm{x}}$ in BAU0 in summer and winter are canceled out in eastern China, and the effects of increasing VOC are larger. The small effects of PC0 in eastern China are also due to its opposite effects in summer and winter. In addition, relative importance of background ozone and methane is also larger in East Asia. Overall and well-designed strategies are required to effectively reduce annual mean surface ozone in East Asia. 


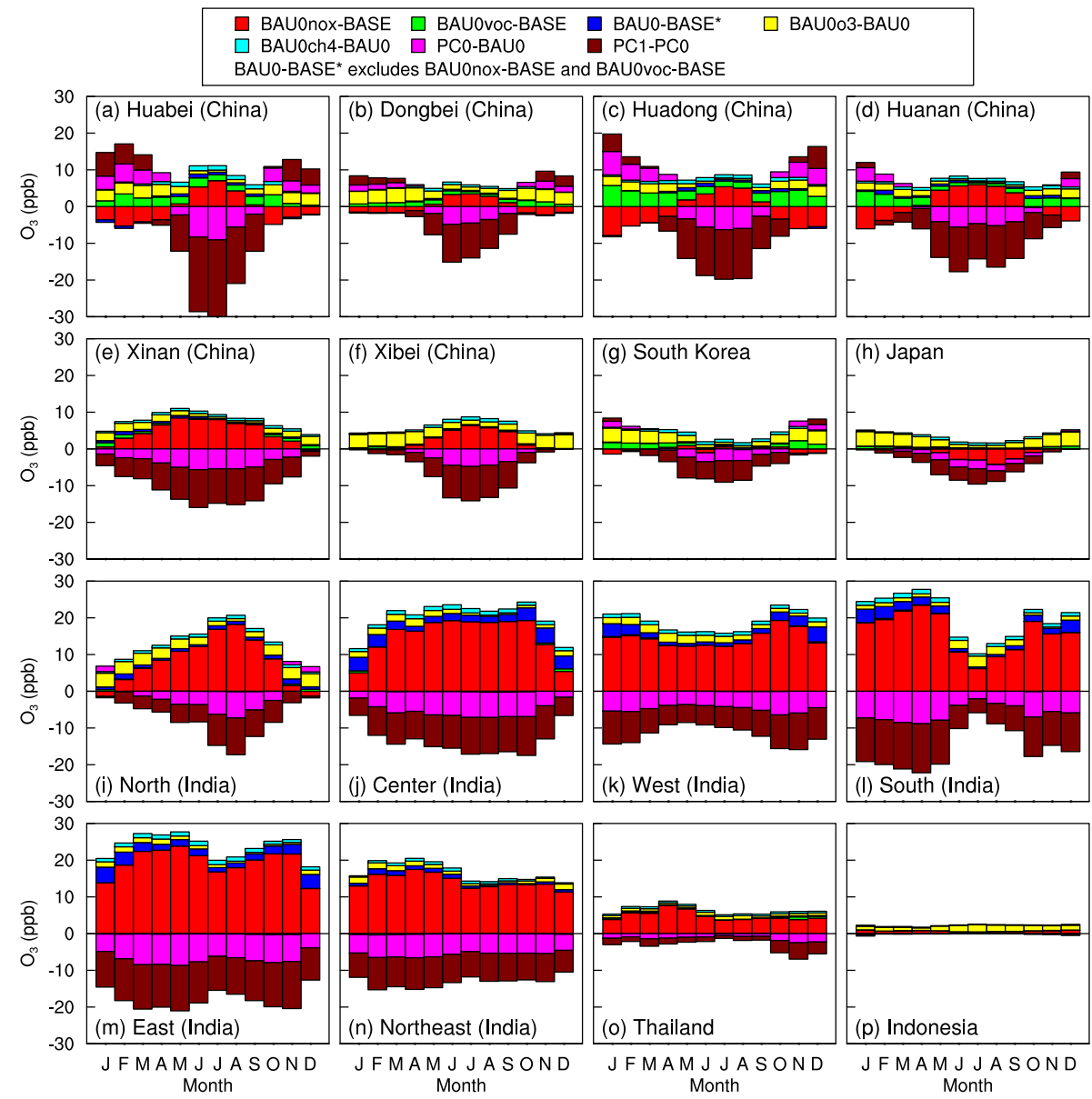

Figure 13. Differences in simulated monthly mean surface ozone concentrations among cases which are averaged over regions in China and India as well as Japan, South Korea, Thailand, and Indonesia.

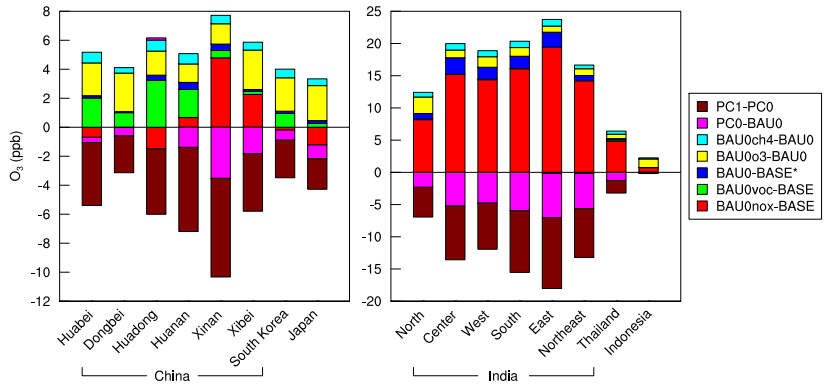

Figure 14. Differences in simulated annual mean surface ozone concentrations among cases which are averaged over regions in China and India as well as Japan, South Korea, Thailand, and Indonesia.

\section{Conclusions}

This study constructed a regional air quality simulation framework to simulate tropospheric ozone over South and East Asia where developing countries are accomplishing rapid economic growth. It demonstrated acceptable performance on tropospheric ozone at regional scale while overestimation of low concentration in summer is one of the remaining issues which other simulation studies are also facing. It is necessary to find out a reason and solve it.

The simulations predicted significant increase of surface ozone around India in BAU0. Increasing $\mathrm{NO}_{\mathrm{x}}$ due to expanding economic activities was a major cause, and warmer weather contributed to it. Surface ozone was predicted to increase also around northeastern China in summer due to increasing $\mathrm{NO}_{\mathrm{x}}$ in BAU0. The additional energy and environmental strategies assumed in $\mathrm{PC} 0$ and $\mathrm{PC} 1$ are expected to effectively reduce surface ozone in the seasons and regions in which surface ozone is significantly increased in BAU0. The situation is a bit complex for annual mean surface ozone in East Asia. Increasing VOC as well as increasing background ozone and methane are also important for it. Various energy and environmental strategies are assumed in PC0 and PC1. It is desired to implement them in order of increasing abatement cost to suppress tropospheric ozone not only in China and India but also surrounding regions. Energy 
strategies assumed in PC0 could simultaneously suppress energy consumption and $\mathrm{CO}_{2}$ emissions.

This study predicted potential future changes of tropospheric ozone due to changes in precursor emissions in the same meteorological field. It is desirable to check if the trend of tropospheric ozone for coming years is following the changes simulated in this study to evaluate the effects of existing strategies in the real atmosphere and to consider additional strategies. Long-term continuous monitoring of pollutant concentrations, periodical update of the emission inventory, and simulations for multiple coming years would be helpful.

The simulation framework constructed in this study can be applied to not only tropospheric ozone but also other air quality issues like acid rain and haze. Especially, air pollution by particulate matter is also one of the major environmental issues in Asia. Ambient particulate matter includes various primary and secondary components. Although this study estimated future $\mathrm{NO}_{\mathrm{x}}$ and VOC emissions, it is necessary to estimate emissions of other components and precursors to predict future concentrations of particulate matter. In addition, strategies implemented in Asian countries other than China and India should affect the air quality over Asia whereas this study mainly focused on China and India. Future energy and emission scenarios in each country are required to evaluate their effects. We hope the outcome of this study will contribute to mitigate energy and environmental issues in Asia as a basis for considering desirable future pathways.

\section{The Supplement related to this article is available online at doi:10.5194/acp-14-9259-2014-supplement.}

Acknowledgements. This study was financially supported by Toyota Motor Corporation.

Edited by: N. L. Ng

\section{References}

Akimoto, H.: Global air quality and pollution, Science, 302, 17161719, doi:10.1126/science.1092666, 2003.

Amann, M., Bertok, I., Borken-Kleefeld, J., Cofala, J., Heyes, C., Höglund-Isaksson, L., Klimont, Z., Nguyen, B., Posch, M., Rafaj, P., Sandler, R., Schöpp, W., Wagner, F., and Winiwarter, W.: Cost-effective control of air quality and greenhouse gases in Europe: modeling and policy applications, Environ. Modell. Softw., 26, 1489-1501, doi:10.1016/j.envsoft.2011.07.012, 2011.

Amann, M., Klimont, Z., and Wagner, F.: Regional and global emissions of air pollutants: recent trends and future scenarios, Annu. Rev. Env. Resour., 38, 7.1-7.25, doi:10.1146/annurev-environ052912-173303, 2013.
Beig, G., Gunthe, S., and Jadhav, D. B.: Simultaneous measurements of ozone and its precursors on a diurnal scale at a semi urban site in India, J. Atmos. Chem., 57, 239-253, doi:10.1007/s10874-007-9068-8, 2007.

Bucsela, E. J., Krotkov, N. A., Celarier, E. A., Lamsal, L. N., Swartz, W. H., Bhartia, P. K., Boersma, K. F., Veefkind, J. P., Gleason, J. F., and Pickering, K. E.: A new stratospheric and tropospheric NO2 retrieval algorithm for nadir-viewing satellite instruments: applications to OMI, Atmos. Meas. Tech., 6, 26072626, doi:10.5194/amt-6-2607-2013, 2013.

Byun, D. W. and Schere, K. L.: Review of the governing equations, computational algorithms, and other components of the Models3 Community Multiscale Air Quality (CMAQ) modeling system overview, Appl. Mech. Rev., 59, 51-77, doi:10.1115/1.2128636, 2006.

Chatani, S., Morikawa, T., Nakatsuka, S., Matsunaga, S., and Minoura H.: Development of a framework for a high-resolution, three-dimensional regional air quality simulation and its application to predicting future air quality over Japan, Atmos. Environ., 45, 1383-1393, doi:10.1016/j.atmosenv.2010.12.036, 2011.

Chatani, S. and Sudo, K.: Influences of the variation in inflow to East Asia on surface ozone over Japan during 1996-005, Atmos. Chem. Phys., 11, 8745-8758, doi:10.5194/acp-11-87452011, 2011.

David, L. M. and Nair, P. R.: Diurnal and seasonal variability of surface ozone and $\mathrm{NO}_{\mathrm{x}}$ at a tropical coastal site: Association with mesoscale and synoptic meteorological conditions, J. Geophys. Res., 116, D10303, doi:10.1029/2010JD015076, 2011.

Dee, D. P., Uppala, S. M., Simmons, A. J., Berrisford, P., Poli, P., Kobayashi, S., Andrae, U., Balmaseda, M. A., Balsamo, G., Bauer, P., Bechtold, P., Beljaars, A. C. M., van de Berg, L., Bidlot, J., Bormann, N., Delsol, C., Dragani, R., Fuentes, M., Geer, A. J., Haimberger, L., Healy, S. B., Hersbach, H., Hólm, E. V., Isaksen, L., Kållberg, P., Köhler, M., Matricardi, M., McNally, A. P., Monge-Sanz, B. M., Morcrette, J.-J., Park, B.-K., Peubey, C., de Rosnay, P., Tavolato, C., Thépaut, J.-N., and Vitart, F.: The ERA-Interim reanalysis: configuration and performance of the data assimilation system, Q. J. Roy. Meteor. Soc., 137, 553-597, doi:10.1002/qj.828, 2011.

Deeter, M. N., Edwards, D. P., Gille, J. C., Emmons, L. K., Francis, G., Ho, S.-P., Mao, D., Masters, D., Worden, H., Drummond, J. R., and Novelli, P. C.: The MOPITT version 4 CO product: algorithm enhancements, validation, and long-term stability, J. Geophys. Res., 115, D07306, doi:10.1029/2009JD013005, 2010.

Dentener, F., Stevenson, D., Cofala, J., Mechler, R., Amann, M., Bergamaschi, P., Raes, F., and Derwent, R.: The impact of air pollutant and methane emission controls on tropospheric ozone and radiative forcing: CTM calculations for the period 19902030, Atmos. Chem. Phys., 5, 1731-1755, doi:10.5194/acp-51731-2005, 2005.

Dentener, F., Stevenson, D., Ellingsen, K., van Noije, T., Schultz, M., Amann, M., Atherton, C., Bell, N., Bergmann, D., Bey, I., Bouwman, L., Butler, T., Cofala, J., Collins, B., Drevet, J., Doherty, R., Eickhout, B., Eskes, H., Fiore, A., Gauss, M., Hauglustaine, D., Horowitz, L., Isaksen, I. S. A., Josse, B., Lawrence, M., Krol, M., Lamarque, J. F., Montanaro, V., Müller, J. F., Peuch, V. H., Pitari, G., Pyle, J., Rast, S., Rodriguez, J., Sanderson, M., Savage, N. H., Shindell, D., Strahan, S., Szopa, S., Sudo, K., Van Dingenen, R., Wild, O., Zeng, G.: The global atmospheric 
environment for the next generation, Environ. Sci. Technol., 40, 3586-3594, doi:10.1021/es0523845, 2006.

Emmons, L. K., Walters, S., Hess, P. G., Lamarque, J.-F., Pfister, G. G., Fillmore, D., Granier, C., Guenther, A., Kinnison, D., Laepple, T., Orlando, J., Tie, X., Tyndall, G., Wiedinmyer, C., Baughcum, S. L., and Kloster, S.: Description and evaluation of the Model for Ozone and Related chemical Tracers, version 4 (MOZART-4), Geosci. Model Dev., 3, 43-67, doi:10.5194/gmd3-43-2010, 2010.

European Commission: Joint Research Centre (JRC)/Netherlands Environmental Assessment Agency (PBL), Emission Database for Global Atmospheric Research (EDGAR), release version 4.1, available at: http://edgar.jrc.ec.europa.eu (last access: 4 October 2013), 2010.

Fiore, A. M., West, J. J., Horowitz, L. W., Naik, V., and Schwarzkopf, M. D.: Characterizing the tropospheric ozone response to methane emission controls and the benefits to climate and air quality, J. Geophys. Res., 113, D08307, doi:10.1029/2007JD009162, 2008.

Fiore, A. M., Naik, V., Spracklen, D. V., Steiner, A., Unger, N., Prather, M., Bergmann, D., Cameron-Smith, P. J., Cionni, I., Collins, W. J., Dalsoren, S., Eyring, V., Folberth, G. A., Ginoux, P., Horowitz, L. W., Josse, B., Lamarque, J.-F., MacKenzie, I. A., Nagashima, T., O’Connor, F. M., Righi, M., Rumbold, S. T., Shindell, D. T., Skeie, R. B., Sudo, K., Szopa, S., Takemura, T., and Zeng, G.: Global air quality and climate, Chem. Soc. Rev., 41, 6663-6683, doi:10.1039/c2cs35095e, 2012.

Ghude, S. D., Pfister, G. G., Jena, C., van der A, R. J., Emmons, L. K., and Kumar, R.: Satellite constraints of nitrogen oxide $\left(\mathrm{NO}_{\mathrm{X}}\right)$ emissions from India based on OMI observations and WRF-Chem simulations, Geophys. Res. Lett., 40, 423-428, doi:10.1029/2012GL053926, 2013.

Guenther, A., Karl, T., Harley, P., Wiedinmyer, C., Palmer, P. I., and Geron, C.: Estimates of global terrestrial isoprene emissions using MEGAN (Model of Emissions of Gases and Aerosols from Nature), Atmos. Chem. Phys., 6, 3181-3210, doi:10.5194/acp-63181-2006, 2006.

Hong Kong Observatory: World Ozone and Ultraviolet Radiation Data Centre (WOUDC) [Data], available at: http://www.woudc. org, last access: 2 July 2012.

IEA: World Energy Outlook 2011, Copernicus Publications, International Energy Agency, Paris, 2011.

IIASA: Global emission fields of air pollutants and GHGs, http://www.iiasa.ac.at/web/home/research/researchPrograms/ Global_emissions.html, last access: 23 January 2013.

India Meteorological Department: World Ozone and Ultraviolet Radiation Data Centre (WOUDC) [Data], available at: http://www. woudc.org, last access: 20 November 2013.

Itahashi, S., Uno, I., and Kim, S.: Seasonal source contributions of tropospheric ozone over East Asia based on CMAQ-HDDM, Atmos. Environ., 70, 204-217, doi:10.1016/j.atmosenv.2013.01.026, 2013.

JMA: World Ozone and Ultraviolet Radiation Data Centre (WOUDC) [Data], available at: http://www.woudc.org, last access: 2 July 2012.

Klimont, Z., Cofala, J., Xing, J., Wei, W., Zhang, C., Wang, S., Kejun, J., Bhandari, P., Mathur, R., Purohit, P., Rafaj, P., Chambers, A., and Amann, M.: Projections of $\mathrm{SO}_{2}, \mathrm{NO}_{\mathrm{x}}$ and car- bonaceous aerosols emissions in Asia, Tellus B, 61, 602-617, doi:10.1111/j.1600-0889.2009.00428.x, 2009.

Kulkarni, Pavan S., Ghude, Sachin D., and Bortoli, D.: Tropospheric ozone (TOR) trend over three major inland Indian cities: Delhi, Hyderabad and Bangalore, Ann. Geophys., 28, 18791885, doi:10.5194/angeo-28-1879-2010, 2010.

Kumar, R., Naja, M., Venkataramani, S., and Wild, O.: Variations in surface ozone at Nainital: A high-altitude site in the central Himalayas, J. Geophys. Res., 115, D16302, doi:10.1029/2009JD013715, 2010.

Kumar, R., Naja, M., Pfister, G. G., Barth, M. C., Wiedinmyer, C., and Brasseur, G. P.: Simulations over South Asia using the Weather Research and Forecasting model with Chemistry (WRFChem): chemistry evaluation and initial results, Geosci. Model Dev., 5, 619-648, doi:10.5194/gmd-5-619-2012, 2012.

Kurokawa, J., Ohara, T., Uno, I., Hayasaki, M., and Tanimoto, H.: Influence of meteorological variability on interannual variations of springtime boundary layer ozone over Japan during 19812005, Atmos. Chem. Phys., 9, 6287-6304, doi:10.5194/acp-96287-2009, 2009.

Lal, S., Naja, M., and Subbaraya, B. H.: Seasonal variations in surface ozone and its precursors over an urban site in India, Atmos. Environ., 34, 2713-2724, doi:10.1016/S1352-2310(99)00510-5, 2000.

Lam, Y. F. and Fu, J. S.: A novel downscaling technique for the linkage of global and regional air quality modeling, Atmos. Chem. Phys., 9, 9169-9185, doi:10.5194/acp-9-9169-2009, 2009.

Lin, M., Holloway, T., Oki, T., Streets, D. G., and Richter, A.: Multiscale model analysis of boundary layer ozone over East Asia, Atmos. Chem. Phys., 9, 3277-3301, doi:10.5194/acp-9-3277-2009, 2009.

Liu, X.-H., Zhang, Y., Xing, J., Zhang, Q., Wang, K., Streets, D. G., Jang, C., Wang, W. X., and Hao, J.: Understanding of regional air pollution over China using CMAQ, part II. Process analysis and sensitivity of ozone and particulate matter to precursor emissions, Atmos. Environ., 44, 3719-3727, doi:10.1016/j.atmosenv.2010.03.036, 2010.

Mauzerall, D. L. and Wang, X. P.: Protecting agricultural crops from the effects of tropospheric ozone exposure: Reconciling science and standard setting in the United States, Europe, and Asia, Annu. Rev. Energ. Env., 26, 237-268, doi:10.1146/annurev.energy.26.1.237, 2001.

Naja, M. and Lal, S.: Surface ozone and precursor gases at Gadanki 13.5 degree N, 79.2 degree E), a tropical rural site in India, J. Geophys. Res., 107, 4197, doi:10.1029/2001JD000357, 2002.

Naja, M., Lal, S., and Chand, D.: Diurnal and seasonal variabilities in surface ozone at a high altitude site Mt Abu (24.6 degree N, 72.7 degree E, 1680 m a.s.1.) in India, Atmos. Environ., 37, 42054215, doi:10.1016/S1352-2310(03)00565-X, 2003.

NASA Goddard Earth Sciences Data and Information Services Center: http://mirador.gsfc.nasa.gov/, last access: 31 August 2012.

NASA Goddard Space Flight Center: http://acd-ext.gsfc.nasa.gov/ Data_services/cloud_slice/new_data.html, last access: 8 October 2012.

NCAR: http://www.acd.ucar.edu/wrf-chem/mozart.shtml, last access: 9 April 2013.

Network Center for EANET: Data Report 2010, available at: http: //www.eanet.asia/product/datarep/datarep10/datarep10.pdf, last access: 31 May 2012. 
Pechony, O., Shindell, D. T., and Faluvegi, G.: Direct top-down estimates of biomass burning $\mathrm{CO}$ emissions using TES and MOPITT vs. bottom-up GFED inventory, J. Geophys. Res.-Atmos., 118, 8054-8066, doi:10.1002/jgrd.50624, 2013.

Reddy, B. S. K., Kumar, K. R., Balakrishnaiah, G., Gopal, K. R., Reddy, R. R., Sivakumar, V., Lingaswamy, A. P., Arafath, S. M., Umadevi, K., Kumari, S. P., Ahammed, Y. N., and Lal, S.: Analysis of diurnal and seasonal behavior of surface ozone and its precursors $\left(\mathrm{NO}_{\mathrm{x}}\right)$ at a semi-arid rural site in Southern India, Aerosol Air Qual. Res., 12, 1081-1094, doi:10.4209/aaqr.2012.03.0055, 2012.

Sharma, S., Goel, A., Gupta, D., Kumar, A., Mishra, A., Kundu, S., Chatani, S., and Klimont, Z.: Emission inventory of non-methane volatile organic compounds from anthropogenic sources in India, Atmos. Environ., submitted, 2014.

Shindell, D., Kuylenstierna, J. C. I., Vignati, E., van Dingenen, R., Amann, M., Klimont, Z., Anenberg, S. C., Muller, N., JanssensMaenhout, G., Raes, F., Schwartz, J., Faluvegi, G., Pozzoli, L., Kupiainen, K., Höglund-Isaksson, L., Emberson, L., Streets, D., Ramanathan, V., Hicks, K., Oanh, N. T. K., Milly, G., Williams, M., Demkine, V., and Fowler, D.: Simultaneously mitigating near-term climate change and improving human health and food security, Science, 335, 183-189, doi:10.1126/science.1210026, 2012.

Sillman, S.: The relation between ozone, $\mathrm{NO}_{\mathrm{x}}$ and hydrocarbons in urban and polluted rural environments, Atmos. Environ., 33, 1821-1845, doi:10.1016/S1352-2310(98)00345-8, 1999.

Skamarock, W. C., Klemp, J. B., Dudhia, J., Gill, D. O., Barker, D. M., Duda, M. G., Huang, X. Y., Wang, W., and Powers, J. G.: A description of the Advanced Research WRF Version 3, NCAR/TN-475+STR, 2008.

Stevenson, D. S., Young, P. J., Naik, V., Lamarque, J.-F., Shindell, D. T., Voulgarakis, A., Skeie, R. B., Dalsoren, S. B., Myhre, G., Berntsen, T. K., Folberth, G. A., Rumbold, S. T., Collins, W. J., MacKenzie, I. A., Doherty, R. M., Zeng, G., van Noije, T. P. C., Strunk, A., Bergmann, D., Cameron-Smith, P., Plummer, D. A., Strode, S. A., Horowitz, L., Lee, Y. H., Szopa, S., Sudo, K., Nagashima, T., Josse, B., Cionni, I., Righi, M., Eyring, V., Conley, A., Bowman, K. W., Wild, O., and Archibald, A.: Tropospheric ozone changes, radiative forcing and attribution to emissions in the Atmospheric Chemistry and Climate Model Intercomparison Project (ACCMIP), Atmos. Chem. Phys., 13, 3063-3085, doi:10.5194/acp-13-3063-2013, 2013.

Tang, G., Li, X., Wang, Y., Xin, J., and Ren, X.: Surface ozone trend details and interpretations in Beijing, 2001-2006, Atmos. Chem. Phys., 9, 8813-8823, doi:10.5194/acp-9-8813-2009, 2009.

Tanimoto, H.: Increase in springtime tropospheric ozone at a mountainous site in Japan for the period 1998-2006, Atmos. Environ., 43, 1358-1363, doi:10.1016/j.atmosenv.2008.12.006, 2009.

USEPA: http://www.epa.gov/ttn/chief/software/speciate/index. html, last access: 23 January 2013.

van der Werf, G. R., Randerson, J. T., Giglio, L., Collatz, G. J., Mu, M., Kasibhatla, P. S., Morton, D. C., DeFries, R. S., Jin, Y., and van Leeuwen, T. T.: Global fire emissions and the contribution of deforestation, savanna, forest, agricultural, and peat fires (19972009), Atmos. Chem. Phys., 10, 11707-11735, doi:10.5194/acp10-11707-2010, 2010.

Van Vuuren, D. P., Edmonds, J., Kainuma, M., Riahi, K., Thomson, A., Hibbard, K., Hurtt, G. C., Kram, T., Krey, V., Lamarque, J.-
F., Masui, T., Meinshausen, M., Nakicenovic, N., Smith, S. J., and Rose, S. K.: The representative concentration pathways: an overview, Climatic Change, 109, 5-31, doi:10.1007/s10584-0110148-z, 2011.

Wang, S., Xing, J., Chatani, S., Hao, J., Klimont, Z., Cofala, J., and Amann, M.: Verification of anthropogenic emissions of China by satellite and ground observations, Atmos. Environ., 45, 63476358, doi:10.1016/j.atmosenv.2011.08.054, 2011.

Wang, T., Wei, X. L., Ding, A. J., Poon, C. N., Lam, K. S., Li, Y. S., Chan, L. Y., and Anson, M.: Increasing surface ozone concentrations in the background atmosphere of Southern China, 19942007, Atmos. Chem. Phys., 9, 6217-6227, doi:10.5194/acp-96217-2009, 2009.

Wei, W., Wang, S., Chatani, S., Klimont, Z. Cofala, J., and Hao, J.: Emission and speciation of non-methane volatile organic compounds from anthropogenic sources in China, Atmos. Environ., 42, 4976-4988, doi:10.1016/j.atmosenv.2008.02.044, 2008.

Whitten, G. Z., Heo, G., Kimura, Y., McDonald-Buller, E., Allen, D. T., Carter, W. P. L., and Yarwood, G.: A new condensed toluene mechanism for Carbon Bond CB05-TU, Atmos. Environ., 44, 5346-5355, doi:10.1016/j.atmosenv.2009.12.029, 2010.

WHO: Air Quality Guidelines, Global Update 2005, Particulate Matter, Ozone, Nitrogen Dioxide and Sulfur Dioxide, WHO Regional Office for Europe, Copenhagen, Denmark, 2006.

Xing, J., Wang, S. X., Chatani, S., Zhang, C. Y., Wei, W., Hao, J. M., Klimont, Z., Cofala, J., and Amann, M.: Projections of air pollutant emissions and its impacts on regional air quality in China in 2020, Atmos. Chem. Phys., 11, 3119-3136, doi:10.5194/acp-113119-2011, 2011.

Xu, X., Lin, W., Wang, T., Yan, P., Tang, J., Meng, Z., and Wang, Y.: Long-term trend of surface ozone at a regional background station in eastern China 1991-2006: enhanced variability, Atmos. Chem. Phys., 8, 2595-2607, doi:10.5194/acp-8-2595-2008, 2008.

Yamaji, K., Ohara, T., Uno, I., Kurokawa, J., Pochanart, P., and Akimoto, H.: Future prediction of surface ozone over east Asia using Models-3 Community Multiscale Air Quality Modeling System and Regional Emission Inventory in Asia, J. Geophys. Res., 113, D08306, doi:10.1029/2007JD008663, 2008.

Young, P. J., Archibald, A. T., Bowman, K. W., Lamarque, J.-F., Naik, V., Stevenson, D. S., Tilmes, S., Voulgarakis, A., Wild, O., Bergmann, D., Cameron-Smith, P., Cionni, I., Collins, W. J., Dalsøren, S. B., Doherty, R. M., Eyring, V., Faluvegi, G., Horowitz, L. W., Josse, B., Lee, Y. H., MacKenzie, I. A., Nagashima, T., Plummer, D. A., Righi, M., Rumbold, S. T., Skeie, R. B., Shindell, D. T., Strode, S. A., Sudo, K., Szopa, S., and Zeng, G.: Preindustrial to end 21 st century projections of tropospheric ozone from the Atmospheric Chemistry and Climate Model Intercomparison Project (ACCMIP), Atmos. Chem. Phys., 13, 20632090, doi:10.5194/acp-13-2063-2013, 2013.

Zhang, Q., Streets, D. G., Carmichael, G. R., He, K. B., Huo, H., Kannari, A., Klimont, Z., Park, I. S., Reddy, S., Fu, J. S., Chen, D., Duan, L., Lei, Y., Wang, L. T., and Yao, Z. L.: Asian emissions in 2006 for the NASA INTEX-B mission, Atmos. Chem. Phys., 9, 5131-5153, doi:10.5194/acp-9-5131-2009, 2009.

Zhao, B., Wang, S. X., Dong, X., Wang, J., Duan, L., Fu, X., Hao, J. M., and Fu, J. S.: Environmental effects of the recent emission changes in China: implications for particulate matter 
pollution and soil acidification, Environ. Res. Lett., 8, 024031, doi:10.1088/1748-9326/8/2/024031, 2013a.

Zhao, B., Wang, S. X., Wang, J., Fu, J. S., Liu, T., Xu, J., Fu, X., and Hao, J. M.: Impact of national $\mathrm{NO}_{\mathrm{x}}$ and $\mathrm{SO}_{2}$ control policies on particulate matter pollution in China, Atmos. Environ., 77, 453-463, doi:10.1016/j.atmosenv.2013.05.012, 2013b.

Zhao, B., Wang, S. X., Liu, H., Xu, J. Y., Fu, K., Klimont, Z., Hao, J. M., He, K. B., Cofala, J., and Amann, M.: $\mathrm{NO}_{\mathrm{X}}$ emissions in China: historical trends and future perspectives, Atmos. Chem. Phys., 13, 9869-9897, doi:10.5194/acp-13-9869-2013, 2013c.
Ziemke, J. R., Chandra, S., Duncan, B. N., Froidevaux, L., Bhartia, P. K., Levelt, P. F., and Waters, J. W.: Tropospheric ozone determined from Aura OMI and MLS: evaluation of measurements and comparison with the Global Modeling Initiative's Chemical Transport Model, J. Geophys. Res., 111, D19303, doi:10.1029/2006JD007089, 2006. 